Working paper: Appropriability and the European Commission's Android Investigation

\title{
Appropriability and the European Commission's Android Investigation
}

\author{
DIRK AUER*
}

\begin{abstract}
This paper seeks to ascertain whether Google's Android licensing terms, which are currently under scrutiny from the European Commission, could be excused under an innovation defense framework. The paper starts by analyzing Google's business model with regard to its Android OS. It then identifies the Commission's main concerns. It argues that Google is simply pursuing a sensible appropriation strategy. Finally, it puts forward a framework which hinges on the concept of "appropriability", and tentatively applies it to Google's behavior.
\end{abstract}

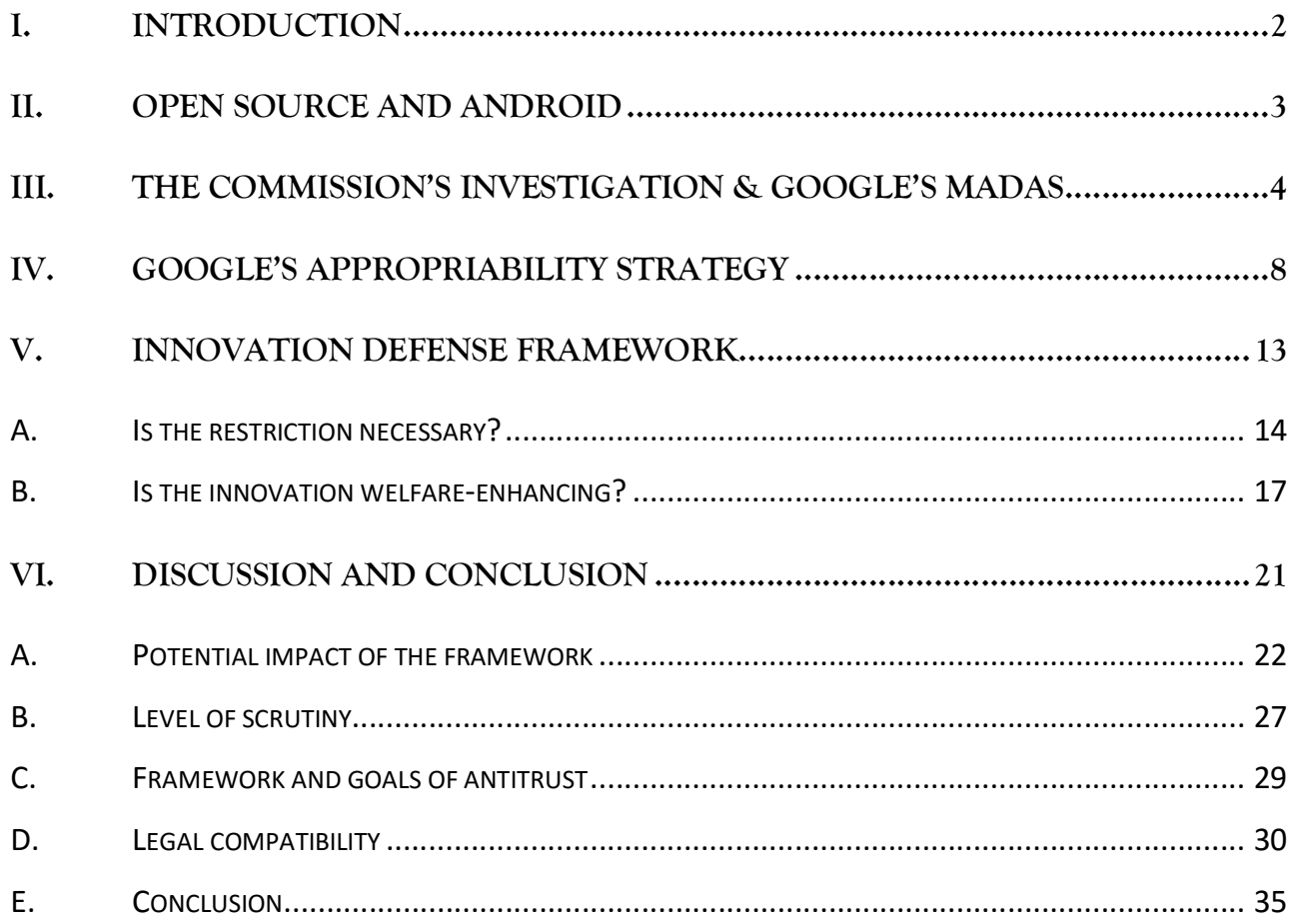

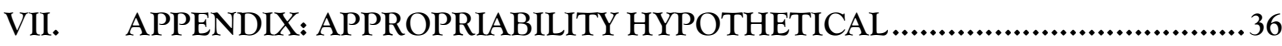

* Research fellow and PhD student, University of Liège (ULg), Law School, Liège Competition and Innovation Institute (“LCII”). dirk.auer@ulg.ac.be. I thank Nicolas Petit and Jorge Marcos Ramos for their precious comments. 


\section{INTRODUCTION}

That every American tech giant will sooner or later come to blows with DG competition is one of the most widespread competition law clichés. Whether true or false, it is precisely the legal quagmire that Google has been wading through since late 2010. The company suffered a further blow in its protracted battle when, in April 2015, the Commission opened a second investigation into the way Google runs its Android mobile operating system. The investigation is still ongoing and the Commission issued a statement of objections on 20 April 2016. ${ }^{1}$ The case turns upon a key question: is Google illegally foreclosing competing apps and services from its Android platform?² Google is the lead contributor to Android, the most widespread smartphone operating system ("OS") in the world. ${ }^{3}$ Crucially, Android is jointly developed and distributed under an Open Source license. Absent certain accompanying factors, Open Source software is generally categorized as a regime of weak appropriability. ${ }^{4}$ This makes the Google Android case an outstanding candidate to apply the innovation defense framework ("the framework") which I shall put forward in this paper.

Section II starts by analyzing Google's business model, focusing mainly on the open source nature of Android. Section III identifies the Commission's main concerns. Section IV argues that Google is primarily pursuing a rational appropriation strategy. Section $\mathrm{V}$ outlines the innovation defense framework and questions whether Google's strategy could be excused under the framework. Finally, section VI discusses the legal and practical challenges raised by the introduction of the framework.

The paper's key intuition is that investments in the Android OS and mobile apps are characterized by a regime of weak appropriability which leaves few incentives to innovate. These weak incentives can be overcome by offering a complementary good - in this case the Google Search engine - and

\footnotetext{
${ }^{1}$ See European Commission, "Antitrust: Commission sends Statement of Objections to Google on Android operating system and applications”, Brussels, April 20, 2016, available at http://europa.eu/rapid/press-release IP-16$1492 \mathrm{en.htm}$.

${ }^{2}$ See European Commission, "Antitrust: Commission opens formal investigation against Google in relation to Android mobile operating system”, Brussels, April 15, 2015, available at http://europa.eu/rapid/press-release_MEMO-15. 4782 en.htm?locale=EN. The Commission seems to be focusing its investigation on both article 101 and 102 TFEU.

3 As of Q2 2015, Android had an 82.8\% share of worldwide smartphone unit shipments. See http://www.idc.com/prodserv/smartphone-os-market-share.jsp. These figures do not indicate how much of this share is occupied by Android "forks" as opposed to pure Android devices.

${ }^{4}$ Linus Dahlander, Appropriation and appropriability in open source software, 9 INTERNATIONAL JOURNAL OF INNOVATION MANAGEMENT, 259-285 (2005).
} 
by locking down the Android platform. ${ }^{5}$ Doing so ensures that the benefits from improvements to the Android OS and apps will spillover to Google through its search engine, thereby boosting incentives to innovate.

\section{OPEN SOURCE AND ANDROID}

To understand the Commission's case it is essential to note that Android is mostly distributed as Open Source software. Though there has been much discussion about the meaning of Open Source, a number of points seem clear. ${ }^{6}$ First, Open Source software must be distributed under a royalty-free license. ${ }^{7}$ Second, the licensor must make the source code of the product available to licensees, thereby enabling them to produce derived works (also referred to as forks). Finally, within some limits designed to protect the reputation of the original author ${ }^{8}$, the license must grant licensees the right to freely distribute any derived works ${ }^{9}$ (though so-called copyleft licenses often require derived works to be distributed under the same terms as the original work $^{10}$ ).

I say that Android is mostly distributed as Open Source software ${ }^{11}$ because it is important to draw a distinction between Android and some of its key applications. On the one hand, the source code for Android is distributed freely. ${ }^{12}$ This source code contains the bare-bones of Android but none of

\footnotetext{
${ }^{5}$ By "locking down", I mean taking various steps to increase its control over the Android platform. These steps are analyzed in detail in section III. Very broadly, Google is using its license agreements with OEMs ensure that its own services feature prominently on Android smartphones.

${ }^{6}$ For a definition of Open Source software, see CHRIS DiBONA \& SAM OCKMAN, OPEN SOURCES: VOICES FROM THE open source ReVOlution 171 (" O'Reilly Media, Inc.". 1999). The definition is given by Bruce Perens and can also be found on the website of the Open Source Initiative: http://opensource.org/osd.

${ }^{7}$ The license must also allow licensees to freely distribute the software.

${ }^{8}$ The idea being that the original author/developer might not want be associated with faulty derived works.

${ }^{9}$ Derivative works in copyright terms.

${ }^{10}$ There is a distinction between standard open source licenses and a subset of licenses called "copyleft". Under a "copyleft" license, the author of the derived work is only permitted to license it under the same terms as the original license. This limits licensees' ability to distribute derived works on a proprietary basis. Not all open source licenses are of the "copyleft" type. See http://opensource.org/faq\#copyleft.

11 Concerning Open Source software, see ANDREW M ST LAURENT, UNDERSTANDING OPEN SOURCE AND FREE SOftWARE licensing (" O'Reilly Media, Inc.". 2004). Steven Weber, The Success of open SOURCE § 897 (Cambridge Univ Press. 2004). On the economics of Open Source platforms, see Josh Lerner \& Jean Tirole, Some Simple Economics of Open Source, JOURNAL Of INDUSTRIAL ECONOMICS, 197-234 (2002). See also Josh Lerner \& Jean Tirole, The scope of open source licensing, 21 JOURNAL OF LAW, ECONOMICS, AND ORGANIZATION, 20-56 (2005). See also Josh Lerner $\&$ Jean Tirole, The Economics of Technology Sharing: Open Source and Beyond, 19 JOURNAL OF ECONOMIC PERSPECTIVES, 99. 120 (2005).

12 This is mostly done under what is known as an Apache 2.0 license. See https://source.android.com/source/licenses.html. Without going into much detail, Apache is a standard open-source license, though not a copyleft one. The standard version of this license notably states that: "... each Contributor hereby grants
} 
Android's marquee apps. Most importantly, it does not include Google Play, which is the linchpin for all other Android applications (without Google Play, it is practically impossible to access Android's rich app ecosystem). This bares-bones Android can, for example, be found on Amazon's Kindle devices which have their own app ecosystem. ${ }^{13}$ It falls squarely within the Open Source definition.

In contrast, Google's marquee applications are proprietary. In practice, this means that OEMs ${ }^{14}$ must obtain Google's consent if they want to preload these applications in the phones they sell. These proprietary applications include most of the apps that users have come to associate with Android smartphones (notably Google Play, Google Maps, Gmail, the YouTube app and Google Calendar). In order to preload these applications, OEMs have to agree to Google's Mobile Application Distribution Agreement (or "MADA"). ${ }^{15}$ Importantly, these agreements do not include any royalty obligations on the part of OEMs - Google's proprietary applications are given away free of charge ${ }^{16}$. It is these MADAs that seem to have prompted the Commission's investigation. ${ }^{17}$

\section{THE COMMISSION'S INVESTIGATION \& GOOGLE'S MADAS}

In its statement of objections, the Commission highlights three potential concerns. ${ }^{18}$ First, it is worried that Google is requiring OEMs to exclusively preinstall some of its applications and services. Second, it is looking into Google's potential limitation of so-called forks (in legal terms, these forks are derivative works based on the Android source code). Finally, the Commission is investigating

to You a perpetual, worldwide, non-exclusive, no-charge, royalty-free, irrevocable copyright license to reproduce, prepare Derivative Works of, publicly display, publicly perform, sublicense, and distribute the Work and such Derivative Works in Source or Object form.". See http://www.apache.org/licenses/LICENSE-2.0.

${ }^{13}$ See https://en.wikipedia.org/wiki/Fire OS, last visited on October 15 2015. See also S. Segan, "How to Run Free Android Apps on the Kindle Fire", PC Magazine, December 2013. Available at http://www.pcmag.com/article2/0,2817,2396276,00.asp.

${ }^{14}$ OEMs are independent manufacturers that produce Android-based smartphones.

15 For a leaked version of Google's "Mobile Application Distribution Agreement", see http://www.benedelman.org/docs/htc-mada.pdf. In the absence of more detailed public information, I will assume that all OEMs are required to agree to these terms in order to sell "full-Android" devices.

${ }^{16}$ Though, as Milton Friedman would say: "There is no such thing as a free lunch". See M. FRIEDMAN, THERE'S NO SUCH THING AS A FREE LUNCH (Open Court. 1975).

${ }^{17}$ See European Commission, supra note 2. "First, the practices mean that Google Search is pre-installed and set as the default, or exclusive, search service on most Android devices sold in Europe. Second, the practices appear to close off ways for rival search engines to access the market, via competing mobile browsers and operating systems".

${ }^{18} \mathrm{Id}$. 
whether Google gave rebates to OEMs and mobile network operators in order to ensure that they pre-install Google Search on their devices. ${ }^{19}$

Most of these concerns seem to stem from Google's MADA, which contains a number of interesting provisions from a competition law standpoint. First, it prevents OEMs from picking and choosing which applications they preinstall. According to Section 2.1 of the MADA, OEMs must preinstall all of Google's “core" applications. ${ }^{20}$ This leaves OEMs with a choice: either they preinstall a complete suite of Google applications (by agreeing to the MADA) or they install none (which means no Google Play). ${ }^{21}$ Second, the MADA includes a number of provisions concerning the default placement of Google's apps on smartphones and the requirement that they be set as the default apps for given tasks. The most noteworthy requirement is that "Google Phone-top Search" should the default search provider. ${ }^{22}$ In addition, icons for Google's core applications must be placed at most "one level” away from the Phone Top (i.e. its home screen). ${ }^{23}$ Finally, OEMs must set Google's Network Location Provider as default. ${ }^{24}$

Why is pre-installation so important? Though most of Google's applications can later be installed by users $^{25}$ via the Google Play application ${ }^{26}$, the same is not true of Google Play itself. If Google Play has not been preloaded on a device, its users are effectively deprived of the "full-Android" experience (i.e. they cannot tap into Android's rich app ecosystem). This is compounded by the fact that Google has moved many key APIs, necessary to run other applications, from the Android Source code to the Google Play application. ${ }^{27}$ The result of these legal and technical measures is clear. OEMs can either

\footnotetext{
${ }^{19}$ There is currently little publicly available information on this third area of concern. Analytically, however, there seems to be little difference between the Commission's first concern and this third one. In this paper I mainly look into the Commission's objection to Google's Android licensing terms, but the paper's analysis could easily be transposed mutatis mutandis to the Commission's third area of concern.

${ }^{20}$ These are listed in section 1.11 of the MADA.

${ }^{21}$ Section 2.1 contains de following passage: “...Devices may only be distributed if all Google Applications (excluding any Optional google Applications) authorized for distribution in the applicable territory are pre-installed on the Device, unless otherwise approved by Google in writing..."

${ }^{22}$ See Section 3.4.(4) of the MADA: "Google Phone-top Search must be set as the default search provider for all Web search access points on the Device."

${ }^{23}$ See section 3.4.(3) of the MADA.

${ }^{24}$ See section 3.8 of the MADA.

${ }^{25}$ For these applications, pre-installation is not such a major issue.

${ }^{26}$ This is Google's equivalent of the Apples App Store.

${ }^{27}$ See R. Amadeo, "Google's iron grip on Android: Controlling open source by any means necessary”, ARSTECHNICA, October 21, 2013, available at http://arstechnica.com/gadgets/2013/10/googles-iron-grip-on-android-controlling-opensource-by-any-means-necessary.
} 
offer a complete suite of Google applications by signing Google's MADA, or they have to offer devices without Google Play - a significant competitive weakness. ${ }^{28}$

The MADA thus makes life more difficult for Google's competitors. It entails both a certain degree of exclusivity and of tying. Google becomes the default provider for a number of services on all "fullAndroid” devices. This includes Google Search, Google Maps, Gmail and YouTube. Competing apps and search engines thus need to convince users to switch to their services because they cannot pay OEMs to set them as default. There have been endless debates about the possibility of anticompetitive foreclosure in such settings - many in connection with the Microsoft cases litigated on both sides of the Atlantic ${ }^{29}$. It is probably too early to take a firm stance on the issue as far as Google is concerned. ${ }^{30}$ Suffice it to say that the MADA makes life more difficult for Google's competitors $^{31}$ and probably increases Google's revenues at their expense, though this does not necessarily entail a reduction of consumer welfare.

\footnotetext{
${ }^{28}$ This is, for example, the case of Amazon's Kindle devices. See supra, note 13.

29 See Case United States of America v. Microsoft Corporation, 253 F.3d 34 (D.C. Cir. 2001). See also See Case T201/04, Microsoft v. Commission, ECR 2007 II-03601, at $§ 979 \& \S 1037$ to 1040 (September 17, 2007). Carlton and Waldman notably show how tying can be used to protect a monopoly position when faced with rapid technological change. See Dennis W Carlton \& Michael Waldman, The strategic use of tying to preserve and create market power in evolving industries, 33 RAND JOURNAL OF ECONOMICS, 194-220 (2002).

${ }^{30}$ On the basis of publicly available information, some authors have argued that Google's conduct is illegal under both US and EU antitrust laws. See notably Benjamin Edelman, Does Google Leverage Market Power Through Tying and Bundling?, 11 JOURNAL OF COMPETITION LAW AND ECONOMICS, 25-33 (2015). Edelman argues that Google uses its dominant position over the Android OS and the YouTube application to stifle competition from rival search engines and applications. Though these concerns should not be dismissed right off that bat, I believe that Edelman's analysis overlooks a number of points. The first concerns Google's innovation defense, of which more in this paper. Other potential efficiencies are also ignored. Providing a more curated Android experience might increase competition with rival platforms (i.e. consumers know what they are getting when they purchase an Android handset and do not have to worry about differences between the experiences offered by rival OEMs). The more curated Android might also serve to avoid fragmentation of the Android platform and reduce development costs. Finally, the fact that there may exist strong inter-brand competition between Android and rival platforms such as Apple's iPhone should not be taken lightly. These concerns have been echoed by a number of commentators, but have not yet been discussed in peer-reviewed scholarship. See notably, Daniel O'Connor, "OBSERVATIONS ON THE ECONOMICS OF MOBILE APP SUITE BUNDLING”, DisRuptive COMPETITION PROJECT, Washington DC, March 3, 2014, available at http://www.projectdisco.org/competition/030314-observations-on-the-economics-of-mobile-app-suite-bundling/\#.VxDowzB942x.

${ }^{31}$ In this case, a key question might be whether competitors could replicate Google Play's application ecosystem, or whether there are other potential distribution channels. Due to network effects, this might prove challenging. On network effects as a market failure see notably Michael L Katz \& Carl Shapiro, Systems competition and network effects, 8 THE JOURNAL OF ECONOMIC PERSPECTIVES, 93-115 (1994). More recently, some scholars have argued that even in the presence of network effects there is still substantial scope for entry by competitors. E Glen Weyl \& Alexander White, Let the Right" One" Win: Policy Lessons from the New Economics of Platforms, 10 COMPETITION POL'Y INT'L, 28 (2014).
} 
The other area of concern is Google's potential limitation of Android "forks". Google is allegedly preventing the producers of these forks from gaining access to its proprietary applications. According to allegations, Google makes it easier for members of the Open Handset Alliance ("OHA") ${ }^{32}$ to install these applications. ${ }^{33}$ In return, members of the OHA agree not to produce rival Android forks. ${ }^{34}$ This is said to limit to creation of forks. Unfortunately, there is very little publicly available information concerning this part of the Commission's case. ${ }^{35}$

Both theories of harm raise complex issues, but there seems to be a common theme. It looks like Google is trying to achieve two goals. First, Google wants to "nudge" ${ }^{36}$ Android users into using Google search and its related applications. Second, it seems to be battling rival forks in order to avoid fragmentation of the Android OS. ${ }^{37}$ These are two sides of the same coin: Google is trying to make as many people as possible use its applications and services. There are two prongs to this strategy: getting a higher share of Android users to opt for Google's services, and ensuring that full-Android devices are as ubiquitous as possible. It will be up to the Commission to decide how harmful these practices are to competition. I will concentrate on a potential justification.

\footnotetext{
32 The Open Handset Alliance is an "alliance of technology and mobile companies which developed Android". Their website is http://www.openhandsetalliance.com/.

${ }^{33}$ See R. Amadeo, supra note 27.

${ }^{34}$ Amadeo, supra note 27, argues that this is confirmed by a message posted on the official Android blog: "While Android remains free for anyone to use as they would like, only Android compatible devices benefit from the full Android ecosystem. By joining the Open Handset Alliance, each member contributes to and builds one Android platform - not a bunch of incompatible versions". Full text available at: http://officialandroid.blogspot.be/2012/09/the-benefits-importance-of-compatibility.html. See also E. Moyer, "Alibaba: Google just plain wrong about our OS”, CNET, September 15, 2012, available at http://www.cnet.com/news/alibaba-google-just-plain-wrong-about-our-os/. The CNET article seems to suggest that smartphone manufacturers cannot gain access to Google's applications if they sell devices which run on Android forks.

${ }^{35}$ Recent developments cast some doubts over these allegations. For example, the One Plus X phone is based on an Android fork but is sold with a full suite of Google applications. See Brian Barrett, "The One Plus X is a steal - and that's why it is so hard to buy”, WIRED, October 30, 2015, available at http://www.wired.com/2015/10/oneplus-x/.

${ }^{36}$ The term nudge is much used in behavioral economics and notably describes the practice of influencing a person's behavior by offering a different default choice (people tend to stick with the default choices they are offered because switching requires more effort). See R.H. THALER \& C.R. SunSteIn, NudGE: IMPROVING DeCisiOnS ABOUT HEALTH, WeAlTH, AND HAPPINESS 83 (Yale University Press. 2008).

${ }^{37}$ Fragmentation of the Android OS represents a key concern for developers of Android applications. See Application Developers Alliance, “App Developer Letter to European Commission: Don't Undermine Android Progress!”, available at http://www.appdevelopersalliance.org/open-letter-eu-govt. If there is too much fragmentation, developers cannot be sure that their applications will run seamlessly on all devices. This raises development costs and makes the Android platform less attractive for developers. In turn, if there are less app developers, the Android platform becomes less attractive for users. Android thus bears the prima facie traits of a two-sided market, as do many operating systems. For a discussion concerning the concept of two-sided markets and its reception in European and US antitrust laws, see Dirk Auer \& Nicolas Petit, Two-Sided Markets and the Challenge of Turning Economic Theory into Antitrust Policy, 60 THE ANTITRUST BuLlETin, 426-461 (2015).
} 


\section{GOOGLE'S APPROPRIABILITY STRATEGY}

The preceding analysis has skirted around a critical issue: why does Google go to great lengths in order to produce an Operating System and applications that it then distributes free of charge? Has the company with the fourth largest market capitalization in the world ${ }^{38}$ become a philanthropic venture? This seems improbable. Instead, we must assume that Google is producing the Android OS and applications in order to generate revenue. ${ }^{39}$ This is where its appropriability strategy comes into play. It is my view that the behavior which has come under scrutiny from the EU Commission might well be essential if Google is to earn a return on its investments in Android and applications. More specifically, I will argue that the Android OS and apps are characterized by a regime of weak appropriability, and that the provisions of Google's MADA can help overcome this obstacle.

Appropriability is the extent to which an innovator captures the social value of its innovation. ${ }^{40}$ Imagine I produce a movie called Antitrust Wars: the FTC Awakens. Imagine further that there are 100 viewers who are each willing to pay 10 to go and see the movie. The social value of the movie is thus 1000. If copyright protection is watertight, I can charge 10 to each viewer. I will thus earn 1000 and achieve $100 \%$ appropriability. But what happens if half of the viewers can pirate the movie and watch

\footnotetext{
${ }^{38}$ Regarding Google's market capitalization, see A. Dullforce, “FT 500 2015”, FINANCIAL TimES, June 19, 2015, available at www.ft.com/ft500.

${ }^{39}$ Note that, strictly speaking, the Android OS is not produced by Google. Instead, Google heads the Android Open Source Project. The project has many different contributors and it is unclear what the exact contribution of each member is. See http://www.openhandsetalliance.com/.

${ }^{40}$ The notion of appropriability, as it is used in this paper, was spearheaded by David Teece. See David J Teece, Profiting from technological innovation: Implications for integration, collaboration, licensing and public policy, 15 RESEARCH POLICY, 287 (1986). Teece referred to "regimes of appropriability" and mostly focused on patents, trade secrets, whether knowledge is codified, and the existence of property rights. Previous scholars such as Schumpeter and Arrow had already dealt with questions of appropriability. This is notably the case for Arrow in his seminal paper. See Kenneth Arrow, Economic welfare and the allocation of resources for invention, in THE RATE AND DIRECTION OF INVENTIVE ACTIVITY: ECONOMIC AND SOCIAL FACTORS 614, (1962). Teece's approach seems original in that it focused on how firms can affect the appropriability of their investments, whereas previous authors tend to take it as given. As far as the novelty of Teece's approach is concerned, see also Sidney G Winter, The logic of appropriability: from Schumpeter to Arrow to Teece, 35 RESEARCH POLICY, 1100-1106 (2006). Winter argues that Teece made a significant contribution to the notion of appropriability, notably by focusing on the use of complementary assets to solve the appropriability problem. Other authors, such as Bator, referred to appropriability but gave it a different meaning. See Francis M Bator, The anatomy of market failure, THE QUARTERLY JOURNAL OF ECONOMICS, 361 (1958). For Bator, appropriability is the ability to exclude people from using a good, rather than the ability to capture the social benefits of an innovation. In other words, Bator's conception of appropriability is binary whereas Teece's is ordinal. Finally, scholars are increasingly using the concept to analyze antitrust questions. See notably See notably Jonathan B Baker, Evaluating appropriability defenses for the exclusionary conduct of dominant firms in innovative industries, AVAILABLE AT SSRN (2014). See also Richard M Brunell, Appropriability in Antitrust: how much is Enough?, 69 ANTITRUST LAW JOURNAL, 1-42 (2001).
} 
it at home, free of charge. ${ }^{41}$ I can now only earn 500, and appropriability has decreased to $50 \%$. Here, the existence of piracy affects appropriability and thus my incentives to invest. For a more detailed hypothetical, see Section VII.

Returning to the case at hand, it is necessary to look at the appropriability regimes that apply to Google's services in the absence of its contested behavior. In that regard, Google produces three categories of products that are relevant to this case: the Android OS, its apps, and its search engine. Appropriability is limited for two out of these three products.

The Android operating system could only be monetized with great difficulty. First, it is distributed under an open source license, which would be hard to overhaul (it is a joint work and moving to a proprietary system would have complex business and intellectual property ramifications ${ }^{42}$ ). Second, other attempts to sell mobile OSs on a proprietary basis have not been particularly successful. ${ }^{43}$ Third, prices tend to be sticky and a move away free from pricing will always prove particularly difficult. ${ }^{44}$ The upshot is that the Android operating system is unlikely to be monetized directly any time soon. Despite the fact that they are covered by various intellectual property rights, the situation is probably similar for Google's applications. By and large, consumer demand for applications seems highly elastic and the marketplace is very competitive. To take just one example, many applications compete

\footnotetext{
${ }^{41}$ This is a massive simplification. In reality, the number of factors that influence appropriability is vast. The legal regime can have an impact through intellectual property, contract, property, antitrust laws, etc. The nature of the good is also important: is it easy to copy or reverse engineer the innovation? Market characteristics such as market power, barriers to entry, the ability to price discriminate, and the ownership of complementary assets also play a significant role.

${ }^{42}$ The many contributors to the Android Project would notably have to agree on a way to split royalties. Moreover, some of them might be strongly opposed to a move away from Open Source.

${ }^{43}$ Microsoft and Blackberry have faced tremendous difficulties in this sector. Blackberry seems to have given up on a proprietary OS and looks set preload Android on its future devices. See Danish Khan, BlackBerry may abandon BB10 operating system and and switch to Android, THE ECONOMIC TIMES, January 29, 2016, available at http://articles.economictimes.indiatimes.com/2016-01-29/news/70178123_1_smartphones-bb10-device. Microsoft's mobile OS has, so far, only achieved a very limited market penetration and its days may be counted. See comScore, comScore Reports December 2015 U.S. Smartphone Subscriber Market Share, COMSCORE, February 4, 2016, available at http://www.comscore.com/Insights/Market-Rankings/comScore-Reports-December-2015-US-Smartphone-SubscriberMarket-Share. Apple is the exception but it benefits from a tremendous brand image and distribution network which Google may not be able to replicate.

${ }^{44}$ Often firms start by offering their premium services for a fee (this is referred to as "freemium pricing"), though it is unclear haw Google could do this. Moreover, even firms that have achieved some success with paid-for applications have recently moved towards free pricing, the most notable example is WhattsApp. See Tom Warren, WhatsApp is now free and promises to stay ad-free, THE VERGE, January 18, 2016, available at http://www.theverge.com/2016/1/18/10785126/whatsapp-free-no-subscription-fees.
} 
with Google Maps and most of them are given away for free. ${ }^{45}$ Starting to charge users for applications like Google Maps does not seem to be a viable option.

Of course, charging users is not the only way to obtain a return on applications or an operating system. Applications and operating systems are often set up as two-sided markets where usage is "subsidized" thanks to advertising and/or the commercialization of users' personal data. ${ }^{46}$ As things stand this does not seem to be the path chosen by Google. Its applications usually do not include inapp advertisements, and personal data only represents a relatively small share of its current revenue ${ }^{47}$. This could change in the future. ${ }^{48}$ In the meantime, it is hard to tell whether moving in this direction represents a viable appropriation strategy for Google.

The final service to analyze is the Google search engine. Here, appropriability seems much stronger. This view is supported by the significant returns that Google earns from its search engine. ${ }^{49}$ Appropriability is reinforced by the fact that Google owns the infrastructure upon which its search engine runs, making it harder to replicate. ${ }^{50}$ Moreover, many features of Google's search algorithms could be protected by patents ${ }^{51}$ while others might prove impossible to reverse engineer/copy ${ }^{52}$. Google can also exert some degree of market power over advertisers that want to access its exclusive

\footnotetext{
${ }^{45}$ Google Maps, Bing Maps, Apple Maps, Waze and TomTom GPS are all offered free of charge.

${ }^{46}$ See David S Evans, Antitrust Economics of Free, COMPETITION POLICY InTERNATIONAL, SPRING (2011).

${ }^{47}$ In 2014, 89.5\% of Google's revenue (worth \$59 Billion) was derived from website advertising. The rest mostly came from paid applications (in particular the services sold to businesses, see https://www.google.com/intx/en/work/apps/business/pricing.html), and music and movies. It should be noted that it is unclear to what extent personal data from apps might have contributed to this advertising revenue. Google's annual report suggests that this contribution was not significant. See Google Inc., Annual Report Pursuant To Section 13 or 15 (d) of the Securities Exchange Act of 1934, for the fiscal year ended December 31, 2014, Section: Results of Operations, available at $\quad$ http://www.sec.gov/Archives/edgar/data/1288776/000128877615000008/goog2014123110k.htm\#s23797ADC5D729B1277E9A635938D34C5.

${ }^{48}$ Though it would represent a massive challenge. Many tech firms have been trying to crack the app-monetizing nut, with varying degrees of success.

${ }^{49}$ In 2014, 68.3\% of Google's revenue came from advertising on Google websites, mainly its search engine. See Google Annual Report, 2014, supra note 47.

${ }^{50}$ See David J Teece, Business models, business strategy and innovation, 43 LONG RANGE PLANNING, 181 (2010).

${ }^{51}$ This is notably the case of the so-called page rank algorithm See L. Page, Method for node ranking in a linked database (Google Patents 2001). Note that patent protection does not necessarily, in and of itself, guarantee a sufficient level of appropriability.

${ }^{52}$ This is notably because Google's algorithm evolves at an exponential rate, rendering human efforts to decrypt it almost futile. See Michael Martinez, Why You Cannot Reverse Engineer Google's Algorithm, SEO THEORY, January 7, 2011, available at http://www.seo-theory.com/2011/01/07/why-you-cannot-reverse-engineer-googles-algorithm/.
} 
users. ${ }^{53}$ Lead time might also play a significant role, meaning that by the time rivals replicate one of Google's improvements - for example, a new search feature ${ }^{54}$ - its investments are already covered and it can move on to new projects. ${ }^{55}$

These three elements give us a first picture of Google's appropriation strategy. Google cannot directly generate revenue from its OS and apps, at least not to a significant extent. Instead, it earns profits by providing a complementary service: its search engine which generates vast advertising revenue. Selling complementary goods has often been highlighted as an appropriation strategy, notably when appropriability is weak for one of two complements. ${ }^{56}$ Moreover, it is a widely used strategy in the field of Open Source software. ${ }^{57}$ Goods are complementary when demand for one is negatively correlated with the price of the other. ${ }^{58}$ This is, for example, the case of razors and blades ${ }^{59}$, internet connections and internet services ${ }^{60}$, and probably operating systems and software.

In the case of Google, the strategy is to increase demand for search by making smartphones and applications more widely available and/or more attractive. ${ }^{61}$ Smartphones should notably lead to increased demand for search engines because users can access search results from a significantly wider

\footnotetext{
${ }^{53}$ Google's search engine seems to match what Armstrong refers to as a "competitive bottleneck". See Mark Armstrong, Competition in two-sided markets, 37 THE RAND JOURNAL OF ECONOMICS, 677 (2006).

${ }^{54}$ Google is continuously adding new features to its search engine, such as Google travel, Google scholar, Google maps, etc.

55 See Neil Gandal, The dynamics of competition in the Internet search engine market, 19 INTERNATIONAL JOURNAL OF INDUSTRIAL ORGANIZATION, 1103-1117 (2001). As early as 2001, Gandal argued that search engines could use short lead times and continued investment in innovation to maintain a competitive advantage. Much has change in the search engine space since then, but his insight still appears relevant.

${ }^{56}$ See Teece, ReSEARCH POLICY, 288 (1986). Teece notably cites operating systems and hardware as an example. Not that tying complementary goods can sometimes be used increase output and transform consumer surplus into producer surplus. This does not seem to be the case here. The economics of complementary goods draw a distinction between goods sold in fixed and variable proportions. Only in the latter case, can a monopolist increase its revenues by tying. See Lester G Telser, A theory of monopoly of complementary goods, JOURNAL OF BUSINESS, 211-230 (1979). In the case of Google and its applications, the goods are sold in fixed proportions. Tying these applications together thus cannot be used as a metering device.

${ }^{57}$ See Dahlander, supra note 4. Dhalander analyzed the appropriation strategy of a number of firms producing open source software rely on complementary assets for appropriability.

${ }^{58}$ For example, goods A and B are complements if decreasing the price of A increases demand for B, and vice versa. See G.J. STIGLER, THE THEORY OF PRICE 28 (Macmillan. 1987).

59 See Randal C Picker, The Razors-and-Blades Myth (s), THE University Of ChICAGO LAW ReVIEW, 225-255 (2011). Though Picker questions the widespread notion that razors handles were given away as a loss leader by Gillette.

${ }^{60}$ Sébastien Broos \& Axel Gautier, Competing one-way essential complements: the forgotten side of net neutrality, AVAILABLE AT SSRN (2015).

${ }^{61}$ See notably James Allworth, Did Google Arm Its Own Enemies With Android, 16 HARVARd BusINESS REVIEW NOVEMBER (2010). As early as 2010, Allworth argued that rival search engines might threaten the profitability of Google's Android project. Allworth adds that this could leave Google at a severe disadvantage compared to Apple.
} 
array of locations. When this is the case, the information they search for might only be relevant if it is obtained immediately. ${ }^{62}$ Smartphones also lead to better matches between eyeballs and advertisers because ads can be "geo-targeted". Both these factors can increase Google's advertising revenues. ${ }^{63}$

Investments in OSs and apps thus appear to generate a positive externality for search engines. ${ }^{64}$ In other words, a dollar invested in OSs and apps could lead to more than a dollar of benefits in search. The problem is that these benefits might not be sufficiently internalized by would-be innovators. Appropriability is a priori weak for mobile OSs and apps. Operating a search engine might solve this problem because part of the positive externality is internalized - the search engine owner reaps some of the benefits from innovations in apps and mobile OSs. This would explain why Google doesn't simply leave the "less profitable" OS and apps segments to its competitors: they might not find it profitable to invest as much as Google in these segments. ${ }^{65}$

In this context, Google's MADA can play a positive role. The MADA ensures that Google Search features prominently on all full-Android smartphones. By doing so, it increases the number of Android users that opt for Google's complementary services, rather than those of its competitors. Confident that an improved mobile experience will translate into greater search profits, Google can comfortably invest in its operating system and apps. In economic terms, the MADA allows Google to internalize a larger share of the social benefits that stem from its investments in mobile Apps and the Android OS. In doing so, it increases the appropriability of Google's investments in these products.

\footnotetext{
${ }^{62}$ For example, if I am walking around a town and looking for a restaurant, I would like to access restaurant reviews for this location immediately. This information will often be irrelevant if I access it too long in advance or after I have made my choice (I might not return to the same town twice).

${ }^{63}$ Google is set up as a two-sided market. See notably Sébastien Broos \& Jorge Marcos Ramos, Google, Google Shopping and Amazon: The Importance of Competing Business Models and Two-Sided Intermediaries in Defining Relevant Markets, AVAILABLE AT SSRN (2015).

${ }^{64}$ There is nothing new about this type of phenomenon. Ronald Coase famously argued that, in the early twentieth century, music publishers would pay singers to perform their compositions in order to boost sales of sheet music (at the time, people needed to hear music live to know what the music would sound like). This was often done either by lump sum payments or by giving performers a share in a song's royalties (these payments internalize the positive externality that live performances had on sheet sales). See Ronald H Coase, Payola in radio and television broadcasting, JOURNAL OF LAW AND ECONOMICS, 269-328 (1979).

${ }^{65}$ Note that this assumes that Google cannot simply conclude bargains with other firms that would induce them to undertake these investments. See Ronald Harry Coase, The Problem of Social Cost, 3 JL \& ECON., 1-44 (1960).
} 
To summarize, there is a sense that due to low appropriability, there is little scope for substantial investments in apps and mobile OSs as standalone products. Google bypasses this problem because it believes that its investments in apps and the Android OS will translate into greater search engine profits. In doing so, Google must ensure that Android users actually opt for Google's profitable services, rather than those of its competitors. The solution is to lock-down its Android platform, thereby nudging users into using its own services.

This is all well and good. It offers an explanation as to why Google moved into mobile operating systems and applications. ${ }^{66}$ But it does not give Google an antitrust innovation defense. For that, there needs to be something more. In the case at hand, it must be that absent its MADA terms, Google would not have found it profitable to invest in certain apps and its Android OS, and that no one else would have done so to the same extent as it currently does. In this section I have tried to explain why this is plausible. In the following section, I look at this claim in more quantitative terms.

\section{INNOVATION DEFENSE FRAMEWORK}

It is one thing to argue - as I have - that the terms of Google's MADA increase its incentives to invest in apps and its OS. However, it is much more complicated to determine whether these increased incentives to innovate outweigh the potentially restrictive effects of the same MADA.

In this paper, I propose an innovation defense framework which authorities could use to deal with this type of question, and tentatively apply it to the Google Android case. Unfortunately, publicly available data on the case is particularly scarce. Accordingly, I shall limit my analysis to highlighting questions that would need to be addressed by the Commission in order to reach a conclusion, and offering preliminary views on those questions.

There are two parts to this innovation defense framework. The first looks at the problem from the innovating firm's point of view and determines whether, with foresight and without the alleged restriction of competition, it would still have invested in the same innovative products or services.

\footnotetext{
${ }^{66}$ More speculatively, similar synergies might explain why Google is investing in fields as varied as Fiber internet connections and self-driving vehicles (who needs roadside advertising when drivers spend their commute time on their mobile devices).
} 
In other words, was a restriction necessary for the firm to innovate ${ }^{27}$ This question is dealt with by focusing on the notion of appropriability. ${ }^{68}$ The second part of the analysis looks at the problem from the point of view of a social planner and asks whether the net surplus generated by the innovation outweighs the harm caused by the restriction of competition. ${ }^{69}$

\section{A. IS THE RESTRICTION NECESSARY?}

The first question is whether a restriction of competition was necessary in order to give rise to the innovation. This involves two steps.

The first step is determine to what extent the contested behavior increases appropriability. In the case at hand, it is thus necessary to compare Google's revenues with and without the allegedly restrictive elements of its MADA. The difference between these two amounts is the extent to which the contested parts of the MADA increase appropriability.

As has already been mentioned, smartphone use generates a positive externality for Google search. Every time a user buys a smartphone, there is a chance that he or she will use it to access a search engine - be it Google's or its competitors'. Google does not fully internalize this effect - some smartphone users opt for rival search engines. This is likely the case even with its MADA in place because users can still opt out of Google's services. Nevertheless, if the MADA increases the number of smartphone users that actually choose Google search, then Google will internalize a higher share

\footnotetext{
${ }^{67}$ Here, necessary means that, with foresight, the company would not have invested in a project absent the conduct that is characterized as a potential restriction of competition. This is distinct from the legal meaning given to the word by the EU Commission.

${ }^{68}$ The paper is not the first to focus on appropriability as an antitrust defense. See Thomas M Jorde \& David J Teece, Innovation and cooperation: implications for competition and antitrust, THE JOURNAL OF ECONOMIC PERSPECTIVES, 75-96 (1990). Jorde and Teece looked at the implications of appropriability for antitrust. See J Gregory Sidak \& David J Teece, Dynamic competition in antitrust law, 5 JOURNAL OF COMPETITION LAW AND ECONOMICS (2009). Sidak and Teece provide further suggestions on how to make antitrust law more "dynamically" efficient. See Brunell, ANTITRUST LAW JOURNAL, 37 (2001). Brunell argues that appropriability considerations do not justify a limitation on antitrust enforcement. See Baker, AVAILABlE AT SSRN, (2014). Baker's framework focuses on the impact that increasing a dominant firm's incentives to invest has on the incentives of rival firms. It is close in spirit to the framework put forward in this paper, though there are marked differences. Most notably, the framework of this paper is limited to a small set of cases where a restriction of competition is necessary to ensure an adequate return on investments, whereas Baker's framework seems to cover a wider array of cases.

${ }^{69}$ Framed differently, the framework shifts some of the risks of innovation away from innovators by allowing them to restrict competition in cases where the innovation would not otherwise have been profitable and where the innovation is welfare-enhancing.
} 
of the externality that smartphone investments exercise on search engines. Google would thus find it more profitable to invest in smartphone OSs and apps.

This effect can be measured by looking at the number of extra users that opt for Google search as a result of the contested provisions of the MADA, and the extra revenue that they generate for Google. This is the type of data that only Google can provide. Nevertheless, requesting such data falls well within the powers of the European Commission. ${ }^{70}$ Moreover, the Commission would be in familiar territory; answering this question is no different to the counterfactual analysis that it brings to bear on most of its investigations.

The second step is to examine whether the increased appropriability was necessary in order to induce the dominant company to innovate. To do so, authorities need (1) to identify innovations that have been brought about by the company and find out how much was invested in them; (2) to ascertain how risky the investments seemed ex ante; and (3) to use this data to compare the expected returns on the investment against the amounts invested. Doing so will prove challenging for authorities.

Authorities should start by identifying relevant innovations and the investments made by the company under investigation in order to bring them to market. ${ }^{71}$ They should look for both new

\footnotetext{
${ }^{70}$ See Article 18 of Council Regulation (EC) No 1/2003 of 16 December 2002 on the implementation of the rules on competition laid down in Articles 81 and 82 of the Treaty, OJ L, January 4, 2003, 1-25.

${ }^{71}$ A particularly thorny is the allocation of common fixed costs. See notably Robert D Willig \& William J Baumol, Using competition as a guide, 11 REGULATION, 29 (1987). Baumol and Willig argue that there is no nonarbitrary way to allocate fixed and common costs to any one area of activity. In their paper, they refer to railroads but this may also be true - to some extent - for a company like Google. For example, some of Google's applications might be based on common source code. There is, however, a difference between an innovation defense and the rate-of-return regulations where cost allocation issues typically crop up. In the case of an innovation defense, the question is not what return a company should earn on investments (there is thus no need to determine how fixed costs should be compensated). Instead, the question is whether an innovation is profitable without a restriction of competition. The upshot is that, in a number of cases, the common fixed costs can be ignored by authorities because another project has been successful enough to fully compensate them (in expected value). In such cases, the fixed costs would have been incurred with or without a restriction of competition and they can thus be taken out of the picture. See also William J Baumol, Predation and the logic of the average variable cost test, JOURNAL OF LAW AND ECONOMICS, 59 (1996). Baumol notes that the allocation of common fixed costs is also a problem in the case antitrust predatory pricing cases. This shows that, though the allocation of fixed costs would be a challenge in the context of the innovation defense framework, it is one that antitrust authorities must routinely face. See also JEAN-JACQUES LAFFONT \& JEAN TIROLE, COMPETITION IN TELECOMMUNICATIONS 145-146 (MIT press. 2001). The authors argue that the best way to avoid cost allocation problems is to design mechanisms which don't incentivize firms to game the system. In that regard, the innovation defense framework has a slight benefit compared to rate-of-return regulations or predatory pricing cases. In the context of the innovation defense framework, firms have mixed incentives. Reporting high costs, will increase the chance that a restriction of competition is deemed necessary, but it will also decrease the net surplus generated by the innovation and thus the likelihood that this net surplus is larger than the deadweight loss (this weighing process is outlined in the following section) This is not the case for rate-of-return regulations or predatory pricing cases - where firms always have an incentive to report high costs.
} 
products and incremental improvements. As far as Google is concerned, obvious contenders are investments in the Android OS before it was first marketed, and investments made to bring incremental improvements to the OS. It might also be useful to look at sums invested in Google's marquee apps. In addition, authorities should not to lose sight of the advertising side of the Google platform. Google might, for example, have invested in research to harness smartphone data in order to provide a better search advertising platform.

The probability of success can also be looked at in a relatively objective manner. Take investments in applications. Clearly, such projects do not always end up as revenue generating products. Authorities could, for example, compare the share of app projects that make their way to end users, compared to those that end up being scrapped. Wikipedia offers a long list of Google's discontinued projects. ${ }^{72}$ Note that discontinued does not necessarily imply failure in the sense of a non-profitable venture. Conversely, some projects might never have turned a profit even if they have not been discontinued. Notable examples of discontinued projects include Google Reader, Orkut and Knol. Once again, only Google could provide a comprehensive list. The share of successful projects to total projects could provide a useful proxy to evaluate the likelihood that Google's investments would be successful.

With this data, the Commission could compare the amounts actually invested by Google to its expected returns with and without the potential restriction of competition. ${ }^{73}$ This is done by taking the revenue generated by the innovation (in both the real and counterfactual settings) and multiplying it by the probability of success. This gives the expected revenue from the projected innovation.

Following this analysis, the Commission could reach one of the following conclusions. First, Google's restriction is necessary if the expected returns without it are smaller than the amounts invested, while the expected returns with it are larger than the amounts invested. With the benefit of foresight,

\footnotetext{
${ }^{72}$ See https://en.wikipedia.org/wiki/List_of_Google_products, last visited on 21 January, 2016.

${ }^{73}$ Especially in the case of long term investments, it is also necessary to compute the net present value of cash inflows after the investment was made. The upshot is that the revenue from innovations will generally need to be slightly larger than the size of past investments might suggest at first sight. This might not be especially relevant for the smartphone industry, where projects seem to have a relatively short-term horizon.
} 
Google would only have invested in the innovation if it knew that its restriction would be excused. ${ }^{74}$ A second, more complicated, case is if the expected returns without the restriction are larger than the amounts invested. Here, it is tempting to conclude that the restriction of competition is unnecessary - Google would have invested anyway. But this is not automatically the case. It is possible that without the restriction the marginal cost of a further incremental innovation would have been inferior to its marginal benefit. ${ }^{75}$ In other words, Google might not have invested in the socially optimal level of innovation, even though it was profitable, because it was not the profit-maximizing level of innovation. If this is the case, a restriction might be necessary, even though the innovation was profitable without it. Third, the case where the expected returns with the restriction are smaller than the amounts invested presents authorities with a conundrum. Whatever authorities decide, with foresight, Google would not have invested. Nevertheless, if the innovation is welfare enhancing, it might still be useful the excuse the restriction of competition. Firms might not know ex ante whether a projected innovation will be profitable or not. Their incentives to invest will be boosted if they can limit their losses when a project isn't profitable.

\section{B. IS THE INNOVATION WELFARE-ENHANCING?}

The final piece of the jigsaw is to determine whether society is better off as a result of the innovation and its accompanying restriction of competition. The framework considers this by weighing the harm from any deadweight loss against the net surplus from the innovation (i.e. the surplus generated by an innovation minus its cost of invention). To do so, a number a questions need to be answered.

For a start, the Commission will have to adapt its analysis depending on the type of innovation that is at stake. A cost- saving innovation ${ }^{76}$ is probably the most straight-forward setting. Imagine a scenario where Google invested in projects which lead to cost-reductions on smartphone units (for

\footnotetext{
${ }^{74}$ I assume here that the fine is large enough to wipe out the entire benefits from the restriction of competition, which might not be so far from the truth. Antitrust sanctions are aimed at ensuring deterrence and, in theory, should thus be set significantly higher than benefits that the restriction generates for the infringer. See notably William M Landes, Optimal Sanctions for Antitrust Violations, 50 UnIVERSITY OF CHICAGO LAW REVIEW, 652-678 (1983).

${ }^{75}$ In that regard see the hypothetical example of the Appendix section. See Section VII.

${ }^{76}$ In economic terms, this is often referred to as a process innovation. A process innovation reduces the costs of the innovator. It is different to a product innovation which differentiates an existing product from competitors' or introduces a new differentiated product. See P. Belleflamme \& M. Peitz, Industrial OrganizAtion: MARKeTS AND StRATEgIES 481 (Cambridge University Press. 2010). Note that, as Belleflamme points out, the distinction between process and product innovations is not watertight. Product innovations can be seen as products that were previously too expensive to produce, but become attainable thanks to a process innovation.
} 
example, by reducing the hardware resources used by its Android OS). For the sake of argument, authorities could simply take the net surplus generated by these cost reductions and weigh them against the deadweight loss brought about by the restriction of competition. Such an analysis is akin to the efficiency tradeoff model put forward by Oliver Williamson as early as $1968^{77}$. There are however two twists. First, authorities need to take the amounts invested by Google into account whereas in a merger setting the only costs are those that stem from a restriction of competition. ${ }^{78}$ Second, the innovation might ultimately be incorporated by competitors (because of a lack of protection, reverse-engineering, etc.) and generate market-wide cost-reductions. The magnitude of this latter effect can be examined by looking at appropriability. ${ }^{79}$ To do so, the Commission needs to ascertain whether imitation is likely and whether it is swift (rapid imitation has a higher present value than slow imitation). The Commission could notably look to the fate of similar innovations in the same industry. In the smartphone sector there is a trend for innovations to be rapidly copied/incorporated by competitors. If the Commission conjectures that this will be the case, then Google's cost-reductions will more likely lead to industry-wide cost reductions, and that should be added to the positive side of the welfare tradeoff. As always, a detailed assessment is necessary to reach a definitive conclusion.

A second scenario is that where the restriction of competition is necessary to create and market a new or improved product. ${ }^{80}$ The most obvious example is the creation and continued development of the Android OS. ${ }^{81}$ The Commission would thus compare the net surplus generated by Android to the deadweight loss that it has identified. In this case, the analysis depends on whether the

\footnotetext{
${ }^{77}$ See Oliver E Williamson, Economies as an antitrust defense: The welfare tradeoffs, THE AMERICAN ECONOMIC REVIEW, 1836 (1968). Williamson proposed a model to weigh the cost reductions brought about by mergers against the deadweight loss they might generate.

${ }^{78}$ Posner disagrees with Williamson on this point, arguing that firms will partake in rent-seeking activities to get their mergers approved. He posits that the cost of such activities should be taken into account. See Richard A Posner, The social cost of monopoly and regulation, 83 JOURNAL OF POLITICAL ECONOMY, 821 (1975). The extent of these rent-seeking investments will hinge upon their marginal benefit to the merging firms. If their marginal benefit decreases rapidly - and this would be my guess - then the world will look more like Williamson's model. On the other hand, Posner's objection becomes more relevant when the marginal benefits are steadier.

${ }^{79}$ See Section IV.

${ }^{80}$ In more economics terms, this is referred to as a product innovation. See supra, note 76. In competition law terms, this type of innovation will either be a differentiated product in an existing relevant market or a product that is so differentiated that it makes up a relevant market by itself.

${ }^{81}$ Other examples include incremental improvements to the Android OS and the creation and improvement of Google's mobile applications.
} 
restriction of competition is identified on the market for the innovation - e.g. the market for smartphone operating systems - or an adjacent market - e.g. the market on which Google operates its search engine ${ }^{82}$. Authorities' task is more complicated when the innovation leads to a new market on which the restriction is present. This would, for example, be the case if the Commission found that Google restricted competition from competing Android forks. Suppose that absent the restriction of competition Google would not have innovated, there would then be no Android and hence there could not be a deadweight loss on the market where the Android OS competes with Android forks. This problem is akin to philosophy's "non-identity problem". ${ }^{83}$ One solution is to ignore the deadweight loss and consider that, because there would not have been a market absent the restriction, it is sufficient for the innovation to generate a positive net surplus. This solution is far from perfect. The fact that an innovation would not have been profitable absent a restriction of competition does not necessarily imply that the innovator would not have invested. ${ }^{84}$ Problematic as it may be, there aren't many other solutions for authorities. It would be even less realistic to assume that the innovation would have taken place anyway, and thus weigh the net surplus against the deadweight loss. Authorities might also be tempted to analyze the problem in a general equilibrium framework (i.e. looking at cross-market effects) though this would prove exceedingly complicated. Accordingly, this last option is usually rejected for antitrust analysis. ${ }^{85}$ On the upside, the non-identity

\footnotetext{
${ }^{82}$ For a more a detailed discussion of Google, the competition it faces and market definition implications, See Broos \& Marcos Ramos, AVAILABle AT SSRN, (2015).

${ }^{83}$ The nonidentity problem broadly states that if some "harm" was a precondition for the existence of something, then there is no counterfactual where the thing exists without the harm (the correct counterfactual is the thing's nonexistence). Accordingly, it is often necessary to ask whether the existence of something plus some amount of harm is preferable to nothing. Hence philosophy's insistence on the idea of a "life worth living", which is better than no life at all. See D. PARFIT, REASONS AND PERSONS 351 (OUP Oxford. 1984). See also James Woodward, The non-identity problem, ETHICS, 804-831 (1986).

${ }^{84}$ The firm might have invested anyway due to bounded rationality, overconfidence or other forms of irrationality, etc. This observation does not necessarily undermine the innovation defense framework put forward herein. In a world with perfect rationality and foresight, the firm would not have invested. If we believe that reality is close enough to this ideal world, then authorities can consider that firms behave as if they were operating in the ideal world.

${ }^{85}$ Antitrust laws on both sides of the Atlantic usually do not take cross-market effects into account. Most prominent economists use partial equilibrium models to deal with competition policy issues (these models assume that the price of all goods other than those in question remain unchanged). See notably J. TIROLE, THE THEORY OF INDUSTRIAL Organization 7 (MIT Press. 1988). See also Belleflamme \& PeITZ, Industrial Organization: Markets and Strategies 24. 2010. In the case at hand, under a general equilibrium approach, authorities would need to ascertain whether the consumers that buy the new product have switched from a product that is priced competitively or not. If the original product is not priced competitively then switching to the new "monopoly" product is not necessarily harmful to welfare. Such an approach would prove challenging, notably because it is not obvious what products consumers are substituting out of when they decide to purchase Android smartphones. On the general equilibrium approach to antitrust analysis, see notably Peter J Hammer, Antitrust beyond competition: market failures, total welfare, and the challenge of intramarket second-
} 
problem disappears when the harm and the benefits are present on separate markets, or when the innovation has not created a separate market. Authorities can then simply weigh the net surplus from the innovation against the deadweight loss.

Be it a product or process innovation, identifying the correct counterfactual will prove challenging. There are two parts to this problem. The first is to determine what level of innovation Google would have adopted absent the restriction of competition ${ }^{86}$ and the second is to determine how competitors would have acted absent Google's conduct. ${ }^{87}$ The extent to which Google's restriction of competition increases appropriability, can give authorities a hint as to how much it would have invested absent a restriction of competition. The more a restriction increases appropriability, the less Google would have likely invested absent the restriction, and vice versa. Although looking at appropriability will give authorities a useful first picture, it may not sufficient. This is because authorities also need to know how much Google would have invested without the extra profits of a restriction of competition (i.e. the counterfactual situation). They cannot simply assume that this investment would be zero without a restriction of competition. ${ }^{88}$ Ideally, authorities would look at what Weyl and Tirole refer to as the "innovation elasticity of supply"; that is the responsiveness of innovative efforts to ex post market power. The higher the elasticity, the more perceived ex post monopoly power increases investments in innovation. ${ }^{89}$ This notion is harder to measure than appropriability - which merely

best tradeoffs, Michigan LAW REVIEW, 849-825 (2000). See also Claus Thustrup Hansen, Second-best antitrust in general equilibrium: a special case, 63 ECONOMICS LETTERS, $193-199$ (1999). cited in R.A. POSNER, ANTITRUST LAW, SECOND EDITION 13 (University of Chicago Press. 2009). These works owe a great debt to Lipsey \& Lancaster's pioneering work on The General Theory of Second Best. See RG Lipsey \& Kelvin Lancaster, The General Theory of Second Best, 24 THE REVIEW OF ECONOMIC STUDIES, 11-32 (1956).

${ }^{86}$ It is one thing to say that Google's restriction was necessary for an innovation to take place to the extent that it did (this is covered in the section on the necessity of Google's alleged restriction of competition). It is another matter to determine what the marketplace would look like absent Google's innovation and concomitant restriction of competition. ${ }^{87}$ Baker deals with a similar question in his appropriability framework. See Baker, AVAILABLE AT SSRN, (2014). Baker's framework determines how of a dominant firm and its rivals would respond to increases to the dominant firm's incentives to invest.

${ }^{88}$ In some exceptional cases, authorities might want to assume that investment would have been zero without an appropriation strategy. This could be the case for projects where there is no middle ground between the highest level of investment and no investment at all - call them "all or nothing" projects. Whether such projects are likely to exist in the real world is another matter. Pharmaceutical products might be an example. It is tempting to think that the amount of work that needs to be done to discover a treatment is more or less fixed. But even in this case I am skeptical. Changes in appropriability might still lead to varying degrees of investment. As appropriability increases, a firm might for example find it profitable to bring in more staff thus increasing its chances of success.

${ }^{89}$ See E Glen Weyl \& Jean Tirole, Market Power Screens Willingness-to-Pay, 127 THE QuARTERLy Journal Of ECONOMICS, 1971-2003 (2012). 
measures the extent to which an innovator internalizes the social benefits of its innovation. At the very least, authorities will need to find information which can give some hint as to how much firms would have invested without the benefit of their contested behavior.

The second part of the counterfactual analysis is to look at the efforts of competitors. If absent Google's restriction, competitors would have picked up the slack and introduced a similar innovation, then not only is Google's innovation not necessarily welfare enhancing but industry investments might be excessive. ${ }^{90}$ To reach this conclusion, there should be a clear sense that, absent Google's innovation and concomitant restriction of competition, another company would have invested to the same extent and been as successful. There are both theoretical and practical reasons to doubt this would have been the case. On the theoretical side, the story of appropriability that was outlined above suggests that Google benefited from a unique advantage that its competitors did not have (i.e. its capacity to internalize a higher share of investments in its smartphone OS and apps). Accordingly, it is unlikely that they would have invested to the same extent as Google. On the practical side, Google's significant market penetration in the browser, online maps, and mobile operating system markets could be seen as support for the theory that it enjoys some advantage over its competitors - possibly because it can invest more thanks to its higher internalization of benefits. Of course, this intuition would need to be confirmed by comparing investments made by Google to those made by its rivals.

Though the counterfactual analysis required to address both these questions might seem daunting, it is less complicated than assessments that the Commission routinely makes in merger cases. Whereas in merger cases there are two unknowns to compare - the future marketplace with the merger and the same market but for the merger -in the case of the innovation defense ${ }^{91}$ there is only one unknown - the state of the market without the restriction.

\section{DISCUSSION AND CONCLUSION}

The preceding sections have attempted to sketch the outlines of an innovation defense framework and applied it to Google's MADA. A number of conclusions can be drawn. There is a sense that Google's

\footnotetext{
${ }^{90}$ This is similar to asking whether or not there is some inefficient duplication of innovative efforts in the industry. This question is covered in more detail below. See Section VI.

${ }^{91}$ As in all abuse of dominant position/monopolization cases.
} 
potential restriction of competition increases the appropriability of its investments in the Android OS and apps - though the magnitude of this effect still needs to be measured. Whether the alleged restrictions were necessary to spur welfare-enhancing innovations is another kettle of fish. Any assessment would hinge upon confidential data that only Google could provide. ${ }^{92}$ Most notably, this includes the sums invested in the Android OS and apps; the number of consumers that opt for Google search as a result of Google's MADA and the extra revenue they generate for Google; the rate of success of Google's innovative projects; and some information that could shed light on Google's “innovation elasticity of supply”. Moreover, the Commission would need to reach complex assessments on matters such as the net surplus generated by Google's innovative products; the ease and speed of imitation by rivals; the deadweight loss generated by Google's alleged restriction; and the extent to which competitors would have introduced similar products absent Google's contested behavior.

Applying the framework would represent a major change for European competition authorities and, accordingly, a number of remarks are in order.

\section{A. POTENTIAL IMPACT OF THE FRAMEWORK}

It is important to note that the desirability of this paper's innovation defense framework hinges largely upon the degree to which firms take ex post antitrust outcomes into account when they decide to invest in innovative projects. This is because innovation policy hinges upon a basic tradeoff which was acutely identified by Arrow ${ }^{93}$. Ex ante, a benevolent dictator would want to give firms incentives to innovate. One way to do so is to reward innovation by granting some degree of ex post market power, most commonly through IP rights. ${ }^{94}$ But once firms have invested, any type of protection is suboptimal from a strictly allocative point of view. Ignoring incentive effects, a benevolent dictator would thus prefer to limit firms' ex post market power. Accordingly, if firms take these ex post antitrust

\footnotetext{
${ }^{92}$ As is often the case, Google will have incentives to present the data in ways that best suits its case and the Commission will have to be vigilant. When it comes to the size of their investments, companies will have mixed incentives. On the one hand, they will want to show that these investments are as large as possible. This increases the number of cases where a restriction of competition is deemed necessary. On the other hand, if they report investments that are too high, it is less likely that their innovation will be considered to be welfare-enhancing.

${ }^{93}$ Arrow, Economic welfare and the allocation of resources for invention 614. 1962.

94 This was recognized well before the emergence of neo-classical economics. This intuition seems to be behind the Copyright and Patent clause of the US Constitution. See U.S. Const. art. I, § 8, cl. 8. "The Congress shall have power... To promote the progress of science and useful arts, by securing for limited times to authors and inventors the exclusive right to their respective writings and discoveries".
} 
outcomes into account when they invest in innovative projects, then antitrust intervention - which tends to limit market power - might sometimes have a chilling effect on investments. Conversely, if firms are not forward-looking with respect to antitrust, then authorities can have their cake and eat it. They can limit ex post market power without chilling firms' investments. In this latter case, the innovation defense framework is mostly without use.

This begs the question: would firms take the possibility of an antitrust innovation defense into account when they invest in potential innovations? First, the impact of such a defense will depend on the likelihood that firms assign to antitrust scrutiny. At first glance, this might not appear to be very high. For example, there are relatively few antitrust cases at the European level if cartels ${ }^{95}$ and mergers ${ }^{96}$ are excluded. ${ }^{97}$ But this only tells half the story. For a start, the national enforcement of the European competitions laws is particularly vigorous. ${ }^{98}$ This significantly affects the likelihood that a given firm will be subject to enforcement actions. Moreover, the ex ante probability of antitrust scrutiny is probably much larger for the subset of firms that actually end up on the receiving end of investigations. Nowhere is this clearer than in the tech sector. All four of the so-called GAFA firms ${ }^{99}$ - Google, Apple, Facebook and Amazon - have been subject to antitrust investigations from either DG competition or NCAs (i.e. national competition authorities). ${ }^{100}$ They are not alone. Other tech

${ }^{95}$ Cartels are much less likely to benefit from an innovation defense framework because they are less likely than other agreements to qualify for exemption under article 101(3) TFEU. On article 101(3) and "hardcore" restrictions, see Alison Jones, The Journey toward an Effects-Based Approach under Article 101 TFEU-The Case of Hardcore Restraints, 55 THE ANTITRUST BULLETIN, 809 (2010). The situation is even stricter in US Antitrust law. In the US cartels fall under a per se prohibition which leaves no room for justifications. On the per se prohibition of cartels, see POSNER, Antitrust Law, Second Edition 39. 2009. Note that the practices which fall under this per se prohibition are narrower than those that might be considered hardcore restrictions under European competition law. Retail price maintenance, for example, falls under the rule of reason in the US but is considered a hardcore restraint in the EU. In any case, on both sides of the Atlantic, cartels are highly unlikely to give rise to a viable innovation defense, even in cases where economics might somehow weigh in favor of the cartel.

${ }^{96}$ The Innovation Defense Framework of this paper would have to be tweaked in order to be applied to mergers. Most notably, it would need to become a forward-looking test because authorities assess mergers ex ante.

${ }^{97}$ The European Commission doesn't publish detailed statistics on these article 101 (excluding cartels) and 102 cases. That said, only a handful of such cases are opened any given year, and not all of them result in sanctions for the firms involved.

98 For statistics on the national enforcement of European Competition laws, see http://ec.europa.eu/competition/ecn/statistics.html. The statistics show that far more cases are initiated by NCAs then by DG Competition (136 against 43 in the year 2015).

99 See FABERNOVEL, GAFAnomics ${ }^{\circledR}$, November 2015, available at http://www.fabernovel.com/work/studygafanomics-2-4-superpowers-network-economy/.

${ }^{100}$ Google is currently subject to two investigations by DG Competition. One is the investigation which is central to this paper, the other concerns its Google Shopping service. See European Commission, "Antitrust: Commission sends Statement of Objections to Google on comparison shopping service”, Brussels, April 15, 2015, available at 
giants have also been under scrutiny, most notably Microsoft, Intel and Qualcomm. ${ }^{101}$ For large tech companies, antitrust investigations might thus be more likely than not. This may also be true for firms in other innovative areas, such as the pharmaceutical sector. ${ }^{102}$ The upshot is that the probability of antitrust scrutiny varies tremendously across firms. As a result, the existence of an effective innovation defense framework will affect different firms to varying degrees.

Second, the usefulness of an innovation defense framework also depends on the impact of increased appropriability - in this case, achieved through strategies which would otherwise run afoul of antitrust laws. In that regard, the evidence is ambiguous.

Cross-sectional studies concerning the potential effect of increased appropriability on innovation are rather inconclusive. ${ }^{103}$ This might be because most of these studies focus on the effect of patent protection, even though it has been argued that patents are far from the best source of appropriability. In other words, it is not clear whether these results would carry through to other forms of appropriability or whether they are specific to patents. The lack of unambiguous positive effects might also be due to the difficulty of finding an effective proxy to measure innovation. Many

http://europa.eu/rapid/press-release MEMO-15-4781 en.htm. Apple was sanctioned in the e-Books market both in the EU and the US. See United States of America v. Apple Inc., U.S. 12 Civ. 2862, 2013; Case U.S. v. Apple Inc, 2nd U.S. Circuit Court of Appeals, No. 13-3741, 2015. See also COMP/AT. 39.847, E-Books (July 25, 2013). Facebook has recently been under scrutiny in Germany for having potentially abused its dominant position in the market for social networks. The German Bundeskartellamt is looking into Facebooks' terms of service regarding user data. See German Bundeskartellamt, "Bundeskartellamt initiates proceeding against Facebook on suspicion of having abused its market power by infringing data protection rules", Bonn March 2, 2016, available at http://www.bundeskartellamt.de/SharedDocs/Meldung/EN/Pressemitteilungen/2016/02_03_2016_Facebook.html. Amazon is currently being investigated by DG competition for its arrangements with publishers regarding e-books. See European Commission, "Antitrust: Commission opens formal investigation into Amazon's e-book distribution arrangements", Brussels, June 11, 2015, available at http://europa.eu/rapid/press-release_IP-15-5166_en.htm.

${ }^{101}$ Microsoft and Intel both lost very high profile competition law cases before the General Court (of the European Union). See Case T-201/04, Microsoft v. Commission, ECR 2007 II-03601, September 17, 2007. See also Case T-286/09, Intel Corp. $v$ European Commission, not yet reported, June 12, 2014. The Intel case is currently under appeal. Qualcomm is subject to two separate investigations, one for predatory pricing and the other for exclusivity arrangements. See European Commission, "Antitrust: Commission opens two formal investigations against chipset supplier Qualcomm", July 16, 2015, available at http://europa.eu/rapid/press-release_IP-15-5383 en.htm.

${ }^{102}$ The pharmaceutical sector has been subject to a protracted inquiry by DG competition. An extensive summary of the various actions that have been undertaken as a result of the inquiry is available on DG competition's website. See European Commission, "Pharmaceuticals: sector inquiry and follow-up", available at http://ec.europa.eu/competition/sectors/pharmaceuticals/inquiry/.

103 The studies focus on patent protection, but do not show a clear trend whereby increased patent protection boosts innovation. Cohen provides a good summary of the results of these studies. See Wesley M Cohen, Fifty years of empirical studies of innovative activity and performance, 1 HANDBOOK OF THE ECONOMICS OF INNOVATION, 186 (2010). 
studies use patent counts but this is problematic. ${ }^{104}$ Other proxies, such as $R \& D$ expenditures and patent citations have also been criticized. ${ }^{105}$ A further concern, is that the relationship between appropriability and innovation might not be linear. ${ }^{106} \mathrm{Up}$ to a point, appropriability - for example through patent protection - might boost innovation. But past that point the relation might change and further increases to appropriability might reduce innovation - for example, because these increases limit positive spillovers. Studies that look at the effect of increased patent protection thus do not have much predictive value as far other sources of appropriability are concerned. ${ }^{107}$

Another strand of studies use surveys of firms' managers. Unlike cross-sectional studies, this method allows researchers to understand how appropriability affects firms' decision making process. Researchers can ask questions such as "would you have innovated if patent protection was not available”, or ask respondents to rank appropriability mechanisms according to their usefulness. One of the big findings of this literature is that firms across different sectors achieve appropriability very differently and, accordingly, they attach distinct values to different appropriability mechanisms. ${ }^{108} \mathrm{As}$ has been mentioned above, firms tend to rank patent protection relatively low ${ }^{109}$ compared to other sources such as lead time, secrecy or the existence of "complementary sales, services or manufacturing

\footnotetext{
${ }^{104}$ See notably Jean O Lanjouw, Ariel Pakes \& Jonathan Putnam, How to count patents and value intellectual property: The uses of patent renewal and application data, 46 THE JOURNAL OF INDUSTRIAL ECONOMICS, 405-432 (1998). The basic problem highlighted by the authors is that patents are extremely heterogeneous; their social value varies tremendously.

${ }^{105}$ See notably John Hagedoorn \& Myriam Cloodt, Measuring innovative performance: is there an advantage in using multiple indicators?, 32 RESEARCH POLICY, 1368-1370 (2003). The authors provide an overview of the various methods used to measure innovation, and some of their advantages and drawbacks.

106 See notably Nancy T Gallini, The economics of patents: Lessons from recent US patent reform, 16 THE JOURNAL OF ECONOMIC PERSPECTIVES, 131-154 (2002).

${ }^{107}$ Increased patent protection might have little effect because it is close to its optimum, whereas boosting other sources of appropriability might yield substantial benefits.

${ }^{108}$ See notably Edwin Mansfield, Patents and innovation: an empirical study, 32 MANAGEMENT SCIENCE, 175-176 (1986). Mansfield shows through surveys that patent protection only had a limited impact on innovation in industries other than the pharmaceuticals industry and, to a lesser extent, the chemicals industry. Mansfield argues that this is because the effectiveness of patents depends on the extent to which they increase imitation costs; and that this increase is more substantial in the chemical and pharmaceutical industries. See also Richard C Levin, Alvin K Klevorick, Richard R Nelson, Sidney G Winter, Richard Gilbert \& Zvi Griliches, Appropriating the returns from industrial research and development, 1987 BROOKINGS PAPERS ON ECONOMIC ACTIVITY, 797 (1987). Levin et al.'s findings are broadly in line with Mansfield's. More recently, these findings were supported by Cohen et al. See Wesley M Cohen, Richard R Nelson \& John P Walsh, Protecting their intellectual assets: Appropriability conditions and why US manufacturing firms patent (or not), 1-30 (2000).

${ }^{109}$ A number of surveys indicate that, in a number of industries, managers do not view patents as a very effective means of appropriability. This is especially true for process patents. A study by Levin et al. concludes that, in $80 \%$ of cases, respondents believed that investments in complementary sales and services efforts ensured more appropriability than patents. See Wesley M Cohen \& Richard C Levin, Empirical studies of innovation and market structure, 2 HANDBOOK OF INDUSTRIAL ORGANIZATION, 1092 (1989). See also Levin, et al., BROOKINGS PAPERS ON ECONOMIC ACTIVITY, 802 (1987). See also Najib Harabi, Appropriability of technical innovations an empirical analysis, 24 RESEARCH POLICY, 981-992 (1995).
} 
capabilities" ${ }^{110}$. These studies tend to reinforce the case for an appropriability defense. Indeed, firms attach varying values to different appropriability mechanisms, and a seemingly week value to patent protection. This suggests that alternative appropriability mechanisms could be valuable, especially in industries where patent protection does not adequately ensure appropriability. ${ }^{111}$

Among these surveys, a study by Cohen et al. shows that complementary sales, services and manufacturing capabilities are a key source of appropriability. ${ }^{112}$ This has important implications for any antitrust innovation defense. Indeed, strategies whereby firms limit access to complementary goods routinely give rise to antitrust intervention. Tying, rebates and refusals to supply can often be used to this effect, and authorities have taken a hard stance against such practices. They worry that dominant firms use them to leverage their significant market power in order to gain shares in markets for complementary goods. But this is just one side of the coin. Cohen et al.'s empirical work confirms Teece's intuition that complementarities are an important source of appropriability. ${ }^{113}$ Together, they provide the strongest argument that complementary good strategies should be analyzed with caution by antitrust authorities. Accordingly, there is a strong potential for an innovation defense in antitrust proceedings which involve large investments in innovation, the ownership of complementary goods, and low appropriability for one of the goods.

Interestingly, both European and US antitrust authorities seem to believe that ex post enforcement can sometimes have a chilling effect on ex ante investments. As far as the EU Commission is concerned, its guidance on the enforcement of article 102 TFEU clearly states that, in some cases, competition enforcement can have such a chilling effect. ${ }^{114}$ The Commission's guidance suggests that such circumstances could provide the basis for the objective justification of otherwise unlawful

\footnotetext{
110 See Cohen, et al., 5 (2000).

${ }^{111}$ Along those lines, Levin cites tying as an alternative to patent protection. See Levin, et al., BROOKINGS PAPERS ON ECONOMIC ACTIVITY, 818 (1987).

${ }^{112}$ See Cohen, et al., 1-30 (2000). Cohen et al. provide the most comprehensive empirical survey of complementarities as an appropriability mechanism.

113 The authors acknowledge this much. See id. at, 7 .

114 The Commission's guidelines on the enforcement of article 102 TFEU state that: "The Commission will consider claims by the dominant undertaking that a refusal to supply is necessary to allow the dominant undertaking to realise an adequate return on the investments required to develop its input business, thus generating incentives to continue to invest in the future, taking the risk of failed projects into account [Emphasis added]." See Communication from the Commission, Guidance on the Commission's enforcement priorities in applying Article 82 of the EC Treaty to abusive exclusionary conduct by dominant undertakings, Official Journal EU, C 45/7, February 24, 2009, §89.
} 
conduct. ${ }^{115}$ Granted, the Commission's statement is only aimed at refusals to supply. This is odd because the potential chilling effect is neither specific to this type of abuse nor is it more considerable in such cases. Quibbles aside, the statement shows that the EU Commission is somewhat sympathetic to the idea that firms take antitrust outcomes into account when they decide to invest, and that these incentives should be protected. The situation is similar in the US. This is most apparent in the late Justice Scalia's majority opinion in Trinko. ${ }^{116}$ Again, the assertion is limited to the implications of forced duties to deal. However, unlike in the EU, the wording is stronger and suggests that the Supreme Court would be sensitive to this issue across the entire gamut of antitrust theories of harm. To summarize, though the empirical evidence on the effect of appropriability is a mixed bag, it leaves the door open to an antitrust innovation defense. At the very least, it seems clear that complementary good strategies, which may sometimes be considered to restrict competition, can potentially increase appropriability. Nevertheless, none of the aforementioned studies perfectly isolates the appropriation strategies which routinely infringe antitrust law. This is true even for those studies which look at complementary sales, services and manufacturing capabilities. Moreover, pinpointing the benefits of increased appropriability in large-scale empirical studies has proved elusive. What does this mean for policymakers? Though there is a case to be made that an antitrust innovation defense could affect firms' investments, there are still gaps in the literature and further research is needed. In the meantime, authorities on both sides of the Atlantic have embraced the idea that unbridled antitrust intervention might chill innovation. The framework put forward in this paper seeks to offer an analytical roadmap which would allow authorities to balance these incentives against the benefits of undistorted competition.

\section{B. LEVEL OF SCRUTINY}

Another question concerns the level of scrutiny that authorities should bring to bear on cases, if they decided to apply the framework. There are a few options. The first is for authorities to presume under certain conditions - that all innovations are welfare enhancing and focus most of their efforts on the firm's appropriation strategy and the necessity of its restriction. I call this the presumption

\footnotetext{
${ }^{115}$ Ibid.

${ }^{116}$ See Verizon Communications Inc. v. Trinko, 540 U.S. 398 (2004), "Firms may acquire monopoly power by establishing an infrastructure that renders them uniquely suited to serve their customers. Compelling such firms to share the source of their advantage is in some tension with the underlying purpose of antitrust law, since it may lessen the incentive for the monopolist, the rival, or both to invest in those economically beneficial facilities."
} 
approach. The second option would be to look at all the points raised in the framework, but rely on proxies rather than precise measurements to reach a conclusion. I call this the qualitative approach. Finally, the Commission could undertake a full-blow analysis whereby it would measure - as much as possible - each of the framework's criteria. I call this the quantitative approach. Though these distinctions are not watertight, they illustrate the varying levels of scrutiny which the Commission could bring to bear on the framework. I would argue that the Commission should at least steer clear of the presumption approach.

Under the presumption approach, the Commission would assume that all innovations are welfare enhancing, so long as they do not constitute "strategic behavior" ${ }^{117}$. This raises two concerns. First, even non-strategic innovations can be detrimental to social welfare. This is notably the case when an extra research project is more costly to society than its benefits in terms new/improved products/process and increased competition. In short, industry investments in research can sometimes be excessive ${ }^{118}$, even in the absence of any "strategic" behavior. There is no reason for the Commission to incentivize the wasteful duplication of innovative efforts. A second objection to the presumption approach is that, because authorities are dealing with what would otherwise be restrictions of competition, there will almost always be reasons to believe that firms have invested for strategic reasons. In the case at hand, one might argue that the profitability of Google's investments was contingent on some rivals exiting the market. ${ }^{119}$ Authorities might thus ask whether the contested provisions of Google's MADA were merely a strategic device designed exclude rivals rather than spur investments, or whether Google's investments where themselves strategic. This type of ambiguity will

\footnotetext{
${ }^{117}$ Behavior is strategic when it is not profitable absent its impact on competitors' reaction. Imagine an incumbent firm that can invest in a cost-reducing innovation in a two-stage entry game. In the first-stage, the incumbent decides whether to invest and, in the second stage, an entrant can decide whether or not to enter the market. This investment has both a direct and a strategic effect. Ignoring the effects of its investment on potential entry, the incumbent will only invest if the cost reductions generate profits that are larger than the cost of invention. This is the direct effect. But the investment can also have an impact on the entry of the rival. For example, the innovation might deter the rival from entering and thus prove profitable even in cases where it is not "directly" profitable. This is the strategic effect. For a detailed explanation of this concept see Belleflamme \& PeITZ, Industrial Organization: Markets and Strategies 400. 2010.

${ }^{118}$ For a more formal treatment, see id. at, 491. See also Jorde \& Teece, THE JOURNAL OF ECONOMIC PERSPECTIVES, 81 (1990). The authors argue that it is sometimes desirable to allow cooperation between competitors to reduce duplication, even if this can decrease horizontal competition/diversity. See also Robert H Frank \& Philip J Cook, Winner-take-all markets, 1 STUdies IN MicROECONOMICS, 131-154 (2013). The authors argue that in “winner-take-all” markets there is often excessive market entry and investment. R. Picker discusses the implications of this paper in his MOOC, see Randal C. Picker, Internet Giants: The Law and Economics of Media Platforms Week 4, Lesson 2-2 (Coursera ed., 2015).

${ }^{119}$ As has already been mentioned, exclusion is often seen as a solution to the public good problem.
} 
probably be a common feature of most cases. Unfortunately, unable to read the minds of dominant firms' top executives, answers will prove elusive. The takeaway from these two objections is that the relevant question isn't as much whether a firm's investments were strategic, but whether they ultimately boosted or limited social welfare. In that regard, the presumption approach does a poor job of sorting the wheat from the chaff.

The qualitative and quantitative approaches each have their advantages and drawbacks. The quantitative approach is more resource-intensive and - until authorities become more familiar with the framework's concepts and choose which models to apply to given situations - there might be might more scope for disagreement. The qualitative approach would require less resources at the expense of precision, relying instead on proxies. But proxies might be hard to come by for some concepts, notably the elasticity of innovation supply. Moreover, weighing the net surplus of an innovation against the deadweight loss of a restriction will require precise measurements in all but extreme cases. The good news is that authorities might not have to commit to one or the other of these two approaches. Instead, they can leave it to firms to put forward the information that they deem most relevant. ${ }^{120}$ With experience, authorities will be better placed to determine what data will work for them in a given case. At this junction, I thus believe it is more important for authorities to flesh out the contours of an eventual innovation defense rather than focus too heavily on the specific type of data they will require from firms.

\section{FRAMEWORK AND GOALS OF ANTITRUST}

Applying this paper's framework would not be uncontroversial, especially in European competition law. A point of concern is that the framework identifies the deadweight loss as the only harm to be taken into account and turns a blind eye to potential transfers of surplus. There are however important reasons to exclude consumer surplus from the equation. Innovations are often public goods. ${ }^{121}$ Solutions to the public good problem frequently involve a sacrifice of ex post consumer

\footnotetext{
${ }^{120}$ There is probably a significant information asymmetry between firms and authorities, where firms detain most of the information. Accordingly, it will probably be up to firms rather to put forward the relevant data. Authorities' task will be to determine whether the data they receive from firms is accurate/credible or not.

${ }^{121}$ Samuelson refers to collective consumption goods in his seminal paper. Paul A Samuelson, The pure theory of public expenditure, THE REVIEW OF ECONOMICS AND STATISTICS, 387-389 (1954). More recent literature refers to "public goods" and defines them as goods that are "non-rival" and "non-excludable". See notably Joseph E Stiglitz, Knowledge as a global public good, 1 Global Public GOODS, 309 (1999). See also Arrow, Economic welfare and the allocation of resources for invention 614. 1962. Arrow shows that the public good problem is particularly acute in the case of innovation.
} 
surplus in order to spur creation - think of patents, copyrights, etc. ${ }^{122}$ Bringing the transfer of surplus into the mix would significantly reduce the scope of any innovation defense framework - the size of the surplus redistribution can be significant compared to that of a deadweight loss ${ }^{123}$. It would tend to exclude some innovations even though they increase the wealth of society as a whole. Furthermore, Innovation is a "black swan" where future benefits are hard to predict. ${ }^{124}$ Because they are acting ex post, authorities will be able to identify the minimum contribution that was brought about by innovations, but not the maximum. There could be new uses for an innovation in the future which authorities will not be able to identify or measure at the time of an investigation. Finally, if an opportunity for an innovation to take place is lost, a new opportunity might not present itself rapidly; unlike the entry of new "static" competitors or new possibilities for antitrust-intervention which are usually still possible further down the road. ${ }^{125}$ The upshot is that there is an asymmetry between the costs to society of losing an innovation and those from the loss of short-run competition. It might thus be preferable to veer on the side of caution and favor type II errors over type I. ${ }^{126}$ Accordingly, I would argue that it is preferable for authorities to weigh the deadweight loss created by a restriction against the net welfare created by innovations, excluding any transfers of surplus from the equation. ${ }^{127}$

\section{LEGAL COMPATIBILITY}

\footnotetext{
122 The other big solution to the public good problem is for the state to subsidize innovation or undertake it itself.

${ }^{123}$ See Williamson, THE AmericAn ECONOMIC REVIEW, 28 (1968).

${ }^{124}$ Black Swans are extremely low probability events with a huge impact. There is a sense that negative black swans cannot be adequately dealt with under a simple expected gains calculation, and that decision makers should strive for robustness against these events. Conversely, positive black swans should be encouraged. For more on this topic, see N.N. TALEB, THE Black Swan: THE Impact OF THE Highly IMProbable (Penguin Books Limited. 2008).

125 Some might counter that accepting an innovation defense too easily will reduce follow-on innovation, thereby generating the same type of social harm that this innovation defense framework is designed to prevent. But there is a significant difference between these two harms. For there to be a follow-on innovation, there must first be an initial innovation. In other words, this innovation defense framework avoids potential chicken and egg problems. It limits potential follow-on innovations only insofar as such limits are necessary to incentivize the initial innovation - without which there would be no follow-on innovation anyway. In that sense, even if the innovation defense framework might appear to limit follow-on innovations from an ex post standpoint, it actually encourages them by increasing initial innovation.

${ }^{126}$ Frank Easterbrook argued forcefully that, when in doubt, antitrust authorities should veer on the side of caution and excuse rather than condemn questionable practices. See Frank H Easterbrook, Limits of antitrust, 63 TEX. L. REV., 15 (1984).

${ }^{127}$ Note that nothing in this framework would prevent authorities from focusing solely on consumer surplus when they establish the existence of an infringement, as opposed to the validity of an innovation defense.
} 
This leaves one last question to answer - and it is a big one: does the Commission have the power to apply the innovation defense framework put forward in this article? Beyond, the customary "where there's a will there's a way", there seem to be few obstacles hindering the Commission.

Most importantly, article 102 TFEU and the ECJ's case law give the Commission a wide - if not infinite -margin of appreciation. Though article 102 TFEU does not explicitly provide for an innovation defense - or any type of efficiency defense for that matter - the Court of Justice has stepped into the breach and introduced the notion of "objective justification". In early case law, the Court simply referred to the idea that otherwise anticompetitive conduct could be "justified" or “objectively necessary" 128 . Unfortunately, these cases do not explicitly lay the foundations for an innovation defense. ${ }^{129}$ The same can be said about more recent case law. In British Airways ${ }^{130}$, the Court acknowledged that a system of rebates could be justified in circumstances where its harm to competition is outweighed by benefits to consumers. Again, the justification does not appear to be about incentives to innovate. Instead, the Court was probably referring of the traditional tradeoff between the initial benefits of rebates - lower prices - and the potential harm from foreclosure.

On the upside, the British Airways strand of case law does makes one significant contribution: it explicitly contemplates scenarios where efficiencies outweigh potential anticompetitive effects. This marks a departure from the early case law which only focused on cases where an abuse was “objectively necessary”. In other words, the Court has shifted from a mostly forms-based approach towards something closer to a cost-benefit analysis. This much was confirmed by the Court in its first Post Danmark ruling. ${ }^{131}$

\footnotetext{
${ }^{128}$ See Case C-27/76, United Brands v Commission, ECR 207, February 17, 1978, §184 \& 189. See Case 311/84, Centre Belge d'études de marché - Télémarketing (CBEM) v Compagnie luxembourgeoise de télédiffusion (CLT) and Information publicité Benelux (IPB), ECR 3261, October 3, 1985, \$27. See also Case T-30/89, Hilti v Commission, ECR II-1439, December 12, 1991, §102 to 119. See also Case T-83/91, Tetra Pak International v Commission (Tetra Pak II), ECR II-755, October 6, $1994, \S 136$.

129 The cases seem to question whether the nature of a product might justify the exclusion of a rival, notably due to interoperability or health and safety reasons. The justifications put forward (without success in Hilti and Tetra Pak) are far-removed from an innovation defense framework. The Court of Justice and General Court do not seem to focus on ex ante incentives or potential social welfare improvements. Instead, the rulings question whether a dominant firm restricted competition to protect its commercial interests rather than to reinforce/abuse its dominant position.

130 See Case C-95/04 P, British Airways $v$ Commission, ECR I-2331, March 15, 2007, §86.

131 The Court acknowledged the existence of these two strands of case law and the difference that exists between them. See Case C-209/10, Post Danmark A/S v Konkurrencerådet, ECR 0000, March 27, 2012, §41.
} 
The Post Danmark Court seems to have made a further stride forward. Paragraph 42 of the ruling notes that a dominant undertaking must show that "the efficiency gains likely to result from the conduct under consideration counteract any likely negative effects on competition and consumer welfare in the affected markets..." ${ }^{132}$ How this should be interpreted is anyone's guess. ${ }^{133}$ At the very least, the Court does not seem to exclude that behavior which reduces consumer welfare - presumably consumer surplus - could be justified. As has already been mentioned, this is crucial for the implementation of an innovation defense because such a defense would often imply some sacrifice of consumer surplus.

Though the British Airways and Post Danmark rulings lay the groundwork for the effective introduction of an innovation defense, the Commission's powers are not entirely without limits. In its Post Danmark ruling, the Court lays down three conditions which efficiency gains must fulfill in order to outweigh abusive behavior: the "efficiency gains" must result from the dominant firm's contested conduct, the conduct must be "necessary" to attain these efficiencies, and the conduct must not lead to the elimination of all or most sources of competition. ${ }^{134}$ That efficiency gains should stem from the contested conduct is relatively uncontroversial. Otherwise, authorities could have their cake and eat by challenging restrictive behavior whilst safeguarding any unrelated benefits. The innovation defense framework falls well within this first condition. By focusing on firms' appropriation strategies, the framework isolates situations where innovation is, at least in theory, conditional upon the restriction of competition. The other two conditions should not pose much of an obstacle to the implementation of the framework. The Court doesn't define "necessary" and, accordingly, there is nothing to suggest that the framework - which finds that a restriction is necessary if an innovation would be unprofitable without it - would not stand up to the ECJ's scrutiny. Likewise, the Court does not give much thought to the "elimination of competition"

\footnotetext{
${ }^{132}$ Ibid. §42. Underlining added.

${ }^{133}$ The Commission offers some insights in its Article 81(3) guidelines. It should be noted, however, that these guidelines have not been explicitly endorsed by the CJEU. Moreover, though they offer some insights, the guidelines do not offer any safer harbors or bright-line rules that might provide some certainty as to the outcome of a given case. See Communication from the Commission, Guidelines on the application of Article 81(3) of the Treaty, Official Journal EU, C 101/97, April 27, 2004, §102-16.

${ }^{134}$ Ibid.

"In that last regard, it is for the dominant undertaking to show that the efficiency gains likely to result from the conduct under consideration counteract any likely negative effects on competition and consumer welfare in the affected markets, that those gains have been, or are likely to be, brought about as a result of that conduct, that such conduct is necessary for the achievement of those gains in efficiency and that it does not eliminate effective competition, by removing all or most existing sources of actual or potential competition".
} 
criterion. In the absence of more detailed guidance, one can only assume that the framework would withstand a legal challenge in all but those cases where it leaves a monopolist with no potential competitors. A final question mark concerns the notion of "efficiency gains" which, once again, are not defined by the Court. Here the answer is more clear-cut. If efficiency gains include cost-reductions - which most people will agree should be the case - then innovations should be considered as efficiency gains. ${ }^{135}$ The upshot is that the Commission has something close to a blank slate when it comes to the introduction of an innovation defense framework. ${ }^{136}$ All that is required, then, is the will to move forward and reorient its policy to make article 102 TFEU proceedings more innovationfriendly.

The introduction of the innovation defense framework might require the Commission to amend its guidance on the enforcement of article 102 (the "guidance paper"). ${ }^{137}$ As things stand, the guidance paper includes a number of paragraphs on efficiency and objective necessity. For the most part, it simply restates the case law of the ECJ. There are however a few details which could preclude the effective implementation of an innovation defense framework. First, the guidance paper states that efficiencies will only be accepted if "no net harm to consumers is likely to arise". Second, the guidance paper tries to define the notion of "elimination of competition", which the ECJ left untouched.

The first point is problematic because an antirust innovation defense will often involve some sacrifice of consumer surplus. Taken literally, the "no net harm to consumers" substantially reduces the scope for innovation defenses. It implies that an efficiency defense is inadmissible as soon as consumer surplus is reduced. Unfortunately, limiting consumer surplus is sometimes necessary to spur innovation. ${ }^{138}$ More fundamentally, the "no net harm to consumers" condition raises a worrying prospect. If a firm's behavior doesn't reduce consumer welfare, many would argue that it shouldn't

\footnotetext{
${ }^{135}$ As previously noted, all innovations can be seen as cost-reductions or process innovations. See note 76.

${ }^{136}$ This is reinforced by the fact that the Commission has a wide margin of appreciation when it comes to "complex economic assessments”. See Case C-56/64, Consten and Grundig v Commission, ECR 299, July 13, 1966, 347. When the General Court was created, there were questions whether the Commission still enjoyed a wide margin of appreciation over economic assessments. In Microsoft, the General Court confirmed that this was the case. See Case T-201/04, Microsoft $v$ Commission, ECR II 3601, September 17, 2007, § 88 \& 89. For a more detailed discussion of the standard of review in European competition law, see notably VAN BAEL \& BELlis, COMPETITION LAW OF THE EUROPEAN COMMUNITY 1200 (Wolters Kluwer Law \& Business. 2010).

${ }^{137}$ See Communication from the Commission, Guidance on the Commission's enforcement priorities in applying Article 82 of the EC Treaty to abusive exclusionary conduct by dominant undertakings, Official Journal EU, C 45/7, February 24, 2009.

${ }^{138}$ This point has already been addressed in Section V.B.
} 
be challenged by antitrust authorities in the first place. In the context of an efficiency defense, the "no net harm to consumers" condition thus embodies a vision of enforcement where the existence of anticompetitive effects is merely an afterthought. This is regrettable.

The second point concerns the concept of "elimination of competition". In a rather lengthy passage, the Commission essentially puts forward a "contestability" ${ }^{139}$ argument: firms in competitive markets innovate in order to steal market shares from their rivals; vigorous competition is thus good for innovation. Accordingly, the Commission sees fit to exclude innovation defenses when conduct leads to market positions close to monopoly. ${ }^{140}$ Vagueness aside, the Commission's stance is awkward. Though it is correct that contestability boosts incentives to innovate, it is only half the story. It has often been argued that incentives to innovate are influenced by two parameters: appropriability and contestability. Both of which can be affected by competition law. Oversimplifying, more ex post market power tends to boost appropriability, whilst lower ex ante market shares increase contestability. Competition enforcement - which tends to promote competition and limit market power - is thus strongly aligned with the contestability parameter. As a result, an innovation defense is most useful in those cases where appropriability is insufficient (competition laws should guarantee sufficient contestability without the need for an innovation defense). This is where the innovation defense framework offers more nuance than the Commission's stance. The framework does not exclude that restrictions of competition leading to a monopoly might sometimes be necessary ${ }^{141}$, but its conditions are harder to fulfill in such cases (the deadweight from a monopoly will tend to be larger and thus harder to compensate).

On the whole, though, there is remarkably little preventing the Commission from introducing a more nuanced innovation defense. ${ }^{142}$ The case law of the ECJ paves the way for such a defense and Commission's guidance paper could easily be amended.

\footnotetext{
139 For a more detailed analysis of appropriability, contestability and innovation, see Carl Shapiro, Competition and Innovation: Did Arrow Hit the Bull's Eye?, in THE RATE AND DiRECTION Of INVENTIVE ACTIVITY REVISITED 361-404, (2011).

${ }^{140}$ The paragraph notably states that "exclusionary conduct which maintains, creates or strengthens a market position approaching that of a monopoly can normally not be justified on the grounds that it also creates efficiency gains." See Commission's Guidance Paper, supra note 137 , at $\$ 30,4^{\circ}$.

${ }^{141}$ Notably when the supply of innovations is particularly elastic.

${ }^{142}$ Interestingly, the Guidance Paper states that in refusal to supply cases the Commission will look at the profitability of investments, their probability of success, and the effect of an obligation to supply on incentives to innovate. See Commission's Guidance Paper, supra note 137 , at $\$ 89$. This is not that different from the framework put forward in this
} 


\section{E. CONCLUSION}

Despite its challenges, it is my belief that the innovation defense framework put forward in this paper could fill the void. If successfully implemented, it would allow for flexible rules which protect firms' incentives to invest. Firms' appropriation strategies would be protected from competition proceedings so long as they ultimately increase social welfare. In a world where IP regimes have been criticized for their one size fits all nature ${ }^{143}$, this could prove to be a boon.

paper (though the Commission adds a number of restrictive conditions). Why such a possibility is limited to refusals to supply is less clear. Any behavior that increases market power can have some impact on incentives to innovate.

${ }^{143}$ See notably Lester C Thurow, Needed: a new system of intellectual property rights, 75 HARVARD BUSINESS REVIEW, 94-107 (1997). See also Michael W Carroll, One Size Does Not Fit All: A Framework for Tailoring Intellectual Property Rights, 70 OHIO STATE LAW JOURNAL, 1361-1434 (2009). 


\section{APPENDIX: APPROPRIABILITY HYPOTHETICAL}

In this hypothetical scenario, I want to see what effect appropriability will have on a firm's investment in innovation. The firm must choose its level of innovation, from tier I to tier IV. Each incremental improvement after tier I, costs an extra 10 to the firm (I assume that the probability of an investment being successful is 1). The marginal benefit to society of each incremental innovation is declining. Innovation I is worth 220 to society; II is worth 236; III is worth 246; and IV is worth 252.

\begin{tabular}{|l|rrrr|}
\hline Incremental innovations & \multicolumn{3}{|c|}{ II } & \multicolumn{3}{c|}{ IV } \\
\hline Total Cost (of inventing) & 100. & 110. & 120. & 130. \\
Incremental cost of invention & 100. & 10. & 10. & 10. \\
Rev. 50\% Appropriability (No R.) & 110. & 118. & 123. & 126. \\
Incremental Rev. & 110. & 8. & 3. & -4. \\
$\pi$ & 10. & 8. & 3. & -4. \\
Value to society & 220. & 236. & 246. & 252. \\
\hline Rev. 55\% Appropriability & 121. & 129.8 & 135.3 & 138.6 \\
Incremental Rev. & 121. & 8.8 & 5.5 & 3.3 \\
$\pi$ & 21. & 19.8 & 15.3 & 8.6 \\
& & & & \\
\hline Rev. 65\% Appropriability & 143. & 153.4 & 159.9 & 163.8 \\
Incremental Rev. & 143. & 10.4 & 6.5 & 3.9 \\
$\pi$ & 43. & 43.4 & 39.9 & 33.8 \\
& & & & \\
\hline Rev. 100\% Appropriability & 220. & 236. & 246. & 252. \\
Incremental Rev. & 220. & 16. & 10. & 6. \\
$\pi$ & 120. & 126. & 126. & 122. \\
\hline
\end{tabular}

I assume that, without a restriction of competition, appropriability is of $50 \%$. Accordingly, the firm can only capture 50\% of each innovation's social benefits (110 for tier I; 118 for tier II, 123 for tier III and 126 for tier IV). Without a restriction of competition, incremental revenue is thus 8 for tier II; 5 for tier III and 3 for tier IV. As a result, without a restriction of competition, the firm will only invest in the level I innovation. For all other tiers, the marginal benefits of an incremental innovation are below its incremental cost. 
But what happens if appropriability were to increase thanks to a restriction of competition? The table shows a number of possibilities, depending on the extent to which the restriction of competition increases appropriability. If appropriability increases to 55\%, the firm will still only invest in the tier I innovation. At $65 \%$, for example, the firm would also invest in the tier II innovation. It is only at $100 \%$ appropriability that the firm would find it profitable to invest in the tier III innovation. Even with $100 \%$ appropriability, the firm would not find it profitable to invest in the tier IV innovation. Note that, from a social welfare standpoint, the tier IV innovation is not desirable, it costs more to create than the added value that it generates.

In this hypothetical, we can also get an idea as to the size of the antitrust restriction that would be optimal from a social welfare standpoint. Let's assume that for, each 5\% increase in appropriability, a restriction of competition leads to 2 extra units of deadweight loss (the harm from the restriction). At $50 \%$ appropriability, the cost of invention is 100 and there is no cost from decreased competition; total welfare is 120 . At $65 \%$, the cost of invention is 110 and there is a loss of 6 , due to the deadweight loss. Total welfare is still 120 . Finally, at $100 \%$ appropriability, the cost of inventing is 130 and there is a deadweight loss of 20 . Total surplus is only of 96.

The upshot is that a social planner will be indifferent between the "no restriction" outcome and the restriction that yields $65 \%$ appropriability. They both lead to 120 of total surplus. It has been argued that authorities should prefer type II errors (false negatives) over type I errors (false convictions). ${ }^{144}$ Accordingly, the firm should be allowed to restrict competition up to a level of $65 \%$ appropriability. This last conclusion can be rephrased. An innovation is socially desirable if its incremental value to society is larger its cost of invention plus the deadweight loss; so long as the restriction of competition is necessary for the innovation to take place.

${ }^{144}$ Easterbrook, TEX. L. REV., 15 (1984). 